\title{
24. PLIOCENE-PLEISTOCENE STABLE ISOTOPE RECORD FOR OCEAN DRILLING PROGRAM SITE 653, TYRRHENIAN BASIN: IMPLICATIONS FOR THE PALEOENVIRONMENTAL HISTORY OF THE MEDITERRANEAN SEA ${ }^{1}$
}

\author{
Robert Thunell, ${ }^{2}$ Douglas Williams, ${ }^{2}$ Eric Tappa,${ }^{2}$ Domenico Rio, ${ }^{3}$ and Isabella Raffi ${ }^{3}$
}

\begin{abstract}
Planktonic foraminiferal oxygen and carbon isotope analyses from Tyrrhenian Sea Ocean Drilling Program (ODP) Site 653 provide a continuous record of the Pliocene-Pleistocene paleoceanographic history of the Mediterranean. Long-term trends in oxygen isotopes primarily reflect changes in global climatic conditions, with a more local or regional signal superimposed on this record. For example, significant enrichments in ${ }^{18} \mathrm{O}$ due to decreases in surface water temperature and/or increases in continental ice volume occurred at 3.1, 2.7, 2.1, 1.6, and 0.4 Ma.

In contrast to most open-ocean results, the early Pliocene $\delta^{18} \mathrm{O}$ record of Site 653 exhibits high-amplitude fluctuations indicative of very unstable climatic conditions in this region. Another unique aspect of this Mediterranean $\delta^{18} \mathrm{O}$ record is the pronounced cooling at the Pliocene/Pleistocene boundary. The carbon isotope record for Site 653 also exhibits high-amplitude variability throughout the Pliocene-Pleistocene. This variability most probably reflects changes in the carbon isotopic composition of the source of Mediterranean surface waters.
\end{abstract}

\section{INTRODUCTION}

Despite two previous Deep Sea Drilling Project (DSDP) legs in the Mediterranean Sea (Legs 13 and $42 \mathrm{~A}$ ), only a very general picture exists regarding the post-Messinian paleoenvironmental history of this region. This is due largely to poor core recovery and sediment mixing caused by rotary drilling. Ocean Drilling Program (ODP) Site 653 in the Tyrrhenian Sea was hydraulically piston cored in an attempt to rectify this situation. One of the primary scientific objectives of this site was to collect a continuous Pliocene-Pleistocene pelagic sequence that would serve as a deep-sea type section for both stratigraphic and paleoenvironmental studies, and also provide a basis for correlating the deepsea and land-based marine records of the Mediterranean region.

Prior to ODP Leg 107, DSDP Site 132 from the Tyrrhenian Basin represented the most complete Pliocene-Pleistocene record available for the Mediterranean. Micropaleontological (Ciaranfi and Cita, 1973; Thunell, 1979), sedimentological (Chamley, 1975) and stable isotopic studies (Keigwin and Thunell, 1979; Thunell and Williams, 1983a) of this site have contributed significantly to our understanding of the paleoclimatic and paleoceanographic evolution of this region. In particular, the oxygen isotopic study of Thunell and Williams (1983a) documented the response of the Mediterranean Sea to major global climatic changes at approximately $3.2 \mathrm{Ma}$ and $2.4 \mathrm{Ma}$. With the exception of numerous isotopic studies of upper Pleistocene piston core material (Vergnaud-Grazzini, 1975; Vergnaud-Grazzini et al., 1977 and 1986; Thunell et al., 1977; Thunell and Williams, 1983b; Buckley et al., 1982), there have been relatively few isotopic studies of the longer term Pliocene-Pleistocene history of the Mediterranean. Vergnaud-Grazzini $(1983,1985)$ has reported data for several early Pliocene samples from Mediterranean DSDP Sites 134, 374 and 375, while Thunell et al. (1985) and Van der Zwaan and Gudjonsson (1986) have presented oxygen isotopic records for the Pliocene land-based marine sequence from the

\footnotetext{
${ }^{1}$ Kastens, K. A., Mascle, J., et al., 1990. Proc. ODP, Sci. Results, 107: College Station, TX (Ocean Drilling Program).

2 Department of Geological Sciences, University of South Carolina, Columbia, SC 29208.

3 Istituto di Geologia, Universita degli Studi di Parma, 43100 Parma, Italy.
}

Capo Rossello region of southern Sicily. These latter two studies were significant in that they demonstrated the potential of such land-based sections for paleoenvironmental reconstructions.

In this paper we present Pliocene-Pleistocene oxygen and carbon stable isotopic records for ODP Site 653 from the Tyrrhenian Sea, and use these records to evaluate the paleoceanographic evolution of the Mediterranean during the last 5 m.y. The semi-isolated nature of the Mediterranean Sea combined with the prevailing climatic regime (evaporation exceeds precipitation) are responsible for the present day lagoonal circulation (inflow at surface and outflow at depth). It is important to understand how and when this hydrographic regime was established. Specifically, we will consider three important problems pertaining to the paleoceanographic history of the Mediterranean: (1) the nature of marine conditions reestablished in the earliest Pliocene following the Messinian salinity crisis; (2) changes in water exchange with the Atlantic through time; and (3) the importance of global climatic events in regulating oceanographic conditions within the Mediterranean.

\section{METHODS}

ODP Site 653 is located in the western Tyrrhenian Sea $\left(40^{\circ} 15^{\prime} \mathrm{N}\right.$, $11^{\circ} 26^{\prime} \mathrm{E} ; 2820 \mathrm{~m}$ water depth) close to DSDP Site 132 . The present study is based primarily on material recovered from Hole 653A (Cores $107-653 \mathrm{~A}-1 \mathrm{H}$ through $-23 \mathrm{X})$ which contained $196 \mathrm{~m}$ ( $93 \%$ recovery) of Pliocene-Pleistocene nannofossil ooze (Mascle et al., this volume). In addition, Core 107-653B-23X was studied in order to provide better coverage of the basal Pliocene.

Stable isotope analyses were carried out following the procedures described in Williams et al. (1977). All samples were analyzed using a VG Isogas Sira 24 isotope ratio mass spectrometer and the data are presented in delta notation $(\delta)$ with respect to the PDB standard. Orbulina universa was selected for analysis because it was stratigraphically the most continuous species. Specimens of $O$. universa from the $355-425$ $\mu \mathrm{m}$ size fraction were analyzed from all samples except those from Core 107-653A-1H. Within this core, O. universa was absent and specimens of Globigerina bulloides were substituted.

Calcium carbonate content was determined for the earliest Pliocene interval of Site 653 (Cores 107-653A-23X and -653B-23X) using a gasometric technique similar to that described in Jones and Kaiteris (1983).

\section{STRATIGRAPHY AND BIOCHRONOLOGY}

Planktonic foraminifers and calcareous nannoplankton have been used to subdivide biostratigraphically the sequence from 
Site 653. Several different planktonic foraminiferal (Cita, 1975; Spaak, 1983) and nannofossil zonations (Martini, 1971; Raffi and Rio, 1979; Okada and Bukry, 1980) are commonly used for Pliocene-Pleistocene material from the Mediterranean, providing good stratigraphic resolution. In addition, the recent studies of Rio et al. (1984 and in press), Zijderveld et al. (1986), Hilgen (1987) and Channell et al. (this volume) have calibrated the various biostratigraphic events used in these zonations to an absolute time scale, thus establishing a biochronologic framework for the Pliocene-Pleistocene of the Mediterranean. In the present study we are using the recently proposed age of approximately 4.84 Ma for the Miocene/Pliocene boundary (Zijderveld et al.,

Table 1. Calcareous plankton biostratigraphic datum levels identified in Site 653.

\begin{tabular}{lrrl}
\hline \multicolumn{1}{c}{ Datum } & $\begin{array}{r}\text { Depth } \\
\text { (mbsf) }\end{array}$ & $\begin{array}{c}\text { Age } \\
\text { (Ma) }\end{array}$ & \multicolumn{1}{c}{ Reference } \\
\hline FO E. huxleyi & 15.6 & 0.26 & Thierstein et al. (1977) \\
FO P. lacunosa & 29.12 & 0.46 & Thierstein et al. (1977) \\
Base of small Gephyrocapsa & 64.97 & 1.10 & Rio et al. (in press) \\
Base of large Gephyrocapsa & 73.80 & 1.32 & Rio et al. (in press) \\
LO G. oceanica & 85.50 & 1.62 & Rio et al. (in press) \\
LO D. brouweri & 88.70 & 1.89 & Rio et al. (in press) \\
FO G. inflata & 98.60 & 1.99 & Hilgen (1987) \\
LO D. pentaradiatus & 111.49 & 2.41 & Rio et al. (1984) \\
LO D. tamalis & 119.22 & 2.60 & Rio et al. (1984) \\
FO G. bononiensis & 138.80 & 3.03 & Hilgen (1987) \\
LO R. pseudoumbilica & 156.60 & 3.56 & Rio et al. (in press) \\
FO D. assymetricus & 169.90 & 3.84 & Rio et al. (in press) \\
FO G. puncticulata & 186.20 & 4.15 & Channell et al., 1988 \\
FO G. margaritae & 209.60 & 4.66 & Channell et al., 1988 \\
\hline
\end{tabular}

Note: $\mathrm{FO}=$ first occurrence and $\mathrm{LO}=$ last occurrence.
1986; Thunell et al. 1987; Channell et al., 1988). According to these studies the Miocene/Pliocene boundary is positioned within the lowermost reversed interval of the Gilbert chron, just below the Thvera subchron. This age is considerably younger than the $5.3 \mathrm{Ma}$ assigned to the boundary by Berggren et al. (1985).

The calcareous plankton biostratigraphic events recognized in Site 653, and their associated ages, are listed in Table 1. An age vs. depth plot of these datum levels indicates that Site 653 contains a very complete Pliocene-Pleistocene sequence (Fig. 1). Sedimentation rates average approximately $42 \mathrm{~m} / \mathrm{m}$.y. below the Calcidiscus macintyrei last occurrence (1.45 Ma) and increase to an average of $60 \mathrm{~m} / \mathrm{m}$.y. above this datum.

\section{RESULTS}

The oxygen and carbon isotopic data for Site 653 are listed in Table 2 and plotted to depth in Figure 2. An examination of the $\delta^{18} \mathrm{O}$ record (Fig. 2) reveals a number of very distinctive features:

1. A long-term enrichment of nearly $3 \% 0$ occurs from the base of the Pliocene to the top of the Pleistocene. Early Pliocene $\delta^{16} \mathrm{O}$ values fluctuate between 0 and $-2 \%$, while late Pleistocene values vary from $1 \%$ to $3 \%$.

2. The lower Pliocene (below $160 \mathrm{~m}$ ) is characterized by high-amplitude (2\%0-3\%0), long-period (200,000-300,000-year) fluctuations.

3. The $2 \%_{0}$ enrichment at $140 \mathrm{~m}$ results in a shift to generally heavier values above this depth.

4. A $2 \%$ enrichment occurs across the Pliocene-Pleistocene boundary $(\sim 83 \mathrm{~m})$, and glacial values above this level are consistently $1.0 \%$ heavier than those below.

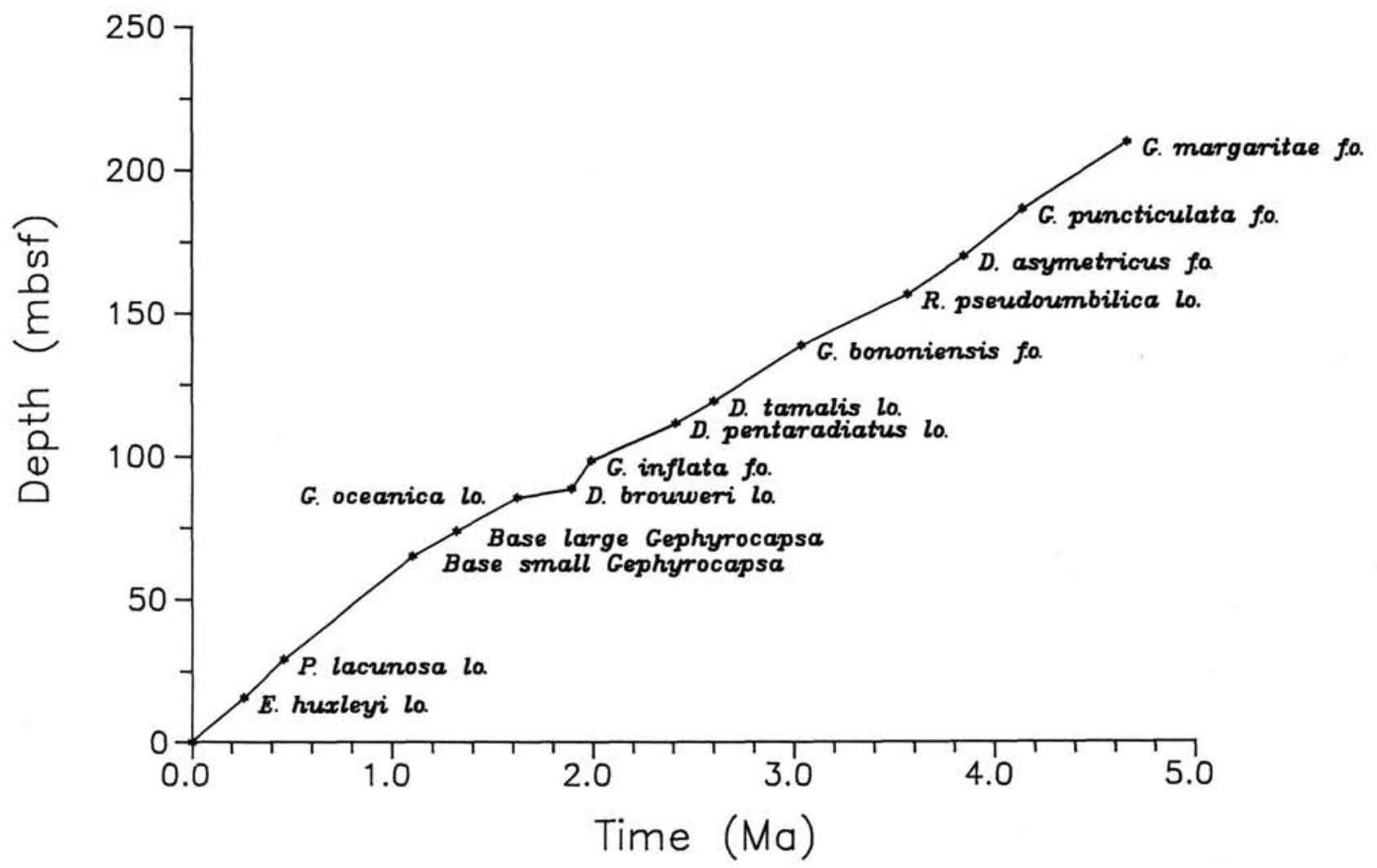

Figure 1. Age vs. depth plot for ODP Site 653. The biostratigraphic datum levels used to construct this plot are indicated. The depths and ages of each datum are given in Table 1. 
Table 2. Site 653 stable isotope data.

\begin{tabular}{llll}
\hline $\begin{array}{c}\text { Core, section, } \\
\text { interval (cm) }\end{array}$ & $\begin{array}{c}\text { Depth } \\
\text { (mbsf) }\end{array}$ & $\delta^{18} \mathrm{O}$ & $\delta^{13} \mathrm{C}$ \\
\hline $107-653 \mathrm{~A}-{ }^{\mathrm{a}}$ & & & \\
& & & \\
$1 \mathrm{H}-1,60$ & 0.60 & 2.24 & -0.57 \\
$1 \mathrm{H}-1,101$ & 1.01 & 3.31 & -1.16 \\
$1 \mathrm{H}-1,120$ & 1.20 & 2.82 & -1.67 \\
$1 \mathrm{H}-2,25$ & 1.75 & 3.38 & -0.97 \\
$1 \mathrm{H}-2,100$ & 2.50 & 2.03 & -1.74 \\
$1 \mathrm{H}-2,120$ & 2.70 & 2.69 & -1.19 \\
$1 \mathrm{H}-3,25$ & 3.25 & 3.03 & -0.06
\end{tabular}

$107-653 \mathrm{~A}^{\mathrm{b}}$

\begin{tabular}{|c|c|c|c|}
\hline $2 \mathrm{H}-1,25$ & 3.95 & 1.10 & 1.30 \\
\hline $2 \mathrm{H}-1,60$ & 4.30 & 1.44 & 1.84 \\
\hline $2 \mathrm{H}-1,118$ & 4.88 & 1.74 & 2.05 \\
\hline $2 \mathrm{H}-2,25$ & 5.45 & 0.70 & 0.73 \\
\hline $2 \mathrm{H}-2,60$ & 5.80 & 1.57 & 1.37 \\
\hline $2 \mathrm{H}-2,99$ & 6.19 & -0.36 & 0.52 \\
\hline $2 \mathrm{H}-3,60$ & 7.30 & 2.94 & 1.68 \\
\hline $2 \mathrm{H}-4,60$ & 8.80 & 2.70 & 1.48 \\
\hline $2 \mathrm{H}-4,120$ & 9.40 & 0.61 & 1.25 \\
\hline $2 \mathrm{H}-5,60$ & 10.30 & 2.24 & 1.64 \\
\hline $2 \mathrm{H}-5,120$ & 10.90 & 2.02 & 1.48 \\
\hline $2 \mathrm{H}-6,60$ & 11.80 & 0.51 & 1.57 \\
\hline $2 \mathrm{H}-6,120$ & 12.40 & 0.95 & 1.31 \\
\hline $3 \mathrm{H}-1,60$ & 13.80 & 2.07 & 1.83 \\
\hline $3 \mathrm{H}-1,120$ & 14.40 & 1.96 & 1.29 \\
\hline $3 \mathrm{H}-2,60$ & 15.30 & 2.66 & 1.36 \\
\hline $3 \mathrm{H}-2,120$ & 15.90 & 1.18 & 1.66 \\
\hline $3 \mathrm{H}-3,60$ & 16.80 & 1.76 & 2.04 \\
\hline $3 \mathrm{H}-3,120$ & 17.40 & 0.65 & 1.50 \\
\hline $3 \mathrm{H}-4,60$ & 18.30 & 0.12 & 1.16 \\
\hline $3 \mathrm{H}-4,120$ & 18.90 & 1.46 & 1.14 \\
\hline $3 \mathrm{H}-5,60$ & 19.80 & 1.57 & 1.19 \\
\hline $3 \mathrm{H}-5,120$ & 20.40 & 1.71 & 1.19 \\
\hline $3 H-6,60$ & 21.30 & 0.43 & -0.02 \\
\hline $3 \mathrm{H}-6,120$ & 21.90 & 1.03 & 1.30 \\
\hline $4 \mathrm{H}-1,60$ & 23.30 & 1.22 & 1.45 \\
\hline $4 \mathrm{H}-1,120$ & 23.90 & 1.08 & 1.70 \\
\hline $4 \mathrm{H}-2,60$ & 24.80 & 1.03 & 1.18 \\
\hline $4 \mathrm{H}-2,120$ & 25.40 & 0.47 & 1.59 \\
\hline $4 \mathrm{H}-3,60$ & 26.30 & 0.48 & 1.04 \\
\hline $4 \mathrm{H}-3,120$ & 26.90 & 0.55 & 0.90 \\
\hline $4 \mathrm{H}-4,60$ & 27.80 & 0.61 & 0.75 \\
\hline $4 \mathrm{H}-4,120$ & 28.40 & 0.66 & 0.66 \\
\hline $4 \mathrm{H}-5,60$ & 29.30 & 2.21 & 1.38 \\
\hline $4 \mathrm{H}-5,120$ & 29.90 & 0.64 & 1.84 \\
\hline $4 \mathrm{H}-6,120$ & 31.40 & 1.01 & 1.22 \\
\hline $5 \mathrm{H}-1,120$ & 33.40 & 1.16 & 1.12 \\
\hline $5 \mathrm{H}-2,60$ & 34.30 & 0.35 & 2.10 \\
\hline $5 \mathrm{H}-2,118$ & 34.88 & 0.18 & 1.31 \\
\hline $5 \mathrm{H}-3,60$ & 35.80 & 1.15 & 1.61 \\
\hline $5 \mathrm{H}-3,120$ & 36.40 & 0.52 & 0.92 \\
\hline $5 \mathrm{H}-4,60$ & 37.30 & -1.95 & 0.47 \\
\hline $5 \mathrm{H}-4,120$ & 37.90 & 0.85 & 1.11 \\
\hline $5 \mathrm{H}-5,60$ & 38.80 & 0.70 & 1.58 \\
\hline $5 \mathrm{H}-5,114$ & 39.34 & 1.21 & 1.36 \\
\hline $5 \mathrm{H}-6,60$ & 40.30 & -0.53 & 0.40 \\
\hline $5 \mathrm{H}-7,60$ & 41.80 & -0.41 & 0.66 \\
\hline $6 \mathrm{H}-1,60$ & 42.20 & 1.39 & 0.95 \\
\hline $6 \mathrm{H}-2,60$ & 43.70 & 0.59 & 0.91 \\
\hline $6 \mathrm{H}-3,60$ & 45.20 & 1.36 & 1.09 \\
\hline $6 \mathrm{H}-3,120$ & 45.80 & 0.58 & 0.80 \\
\hline $6 \mathrm{H}-4,60$ & 46.70 & 0.24 & 1.48 \\
\hline $6 \mathrm{H}-5,62$ & 48.22 & 0.76 & 1.33 \\
\hline $6 \mathrm{H}-5,120$ & 48.80 & 0.48 & 1.47 \\
\hline $6 \mathrm{H}-6,62$ & 49.72 & 0.43 & 1.27 \\
\hline $7 \mathrm{H}-1,56$ & 51.56 & 0.82 & 1.30 \\
\hline $7 \mathrm{H}-1,120$ & 52.20 & 1.23 & 1.64 \\
\hline $7 \mathrm{H}-2,60$ & 53.10 & 1.52 & 1.10 \\
\hline $7 \mathrm{H}-2,120$ & 53.70 & 1.06 & 0.91 \\
\hline $7 \mathrm{H}-3,60$ & 54.60 & 1.41 & 0.84 \\
\hline $7 \mathrm{H}-3,120$ & 55.20 & 0.93 & 1.37 \\
\hline $7 \mathrm{H}-4,65$ & 56.15 & 0.53 & 0.72 \\
\hline $7 \mathrm{H}-4,120$ & 56.70 & 0.47 & 1.08 \\
\hline $7 \mathrm{H}-5,60$ & 57.60 & -0.96 & 0.69 \\
\hline $7 \mathrm{H}-5,120$ & 58.20 & -0.29 & -0.61 \\
\hline $7 \mathrm{H}-6,59$ & 59.09 & 1.19 & 1.29 \\
\hline $7 \mathrm{H}-6,120$ & 59.70 & 0.35 & 0.43 \\
\hline
\end{tabular}

Table 2 (continued).

\begin{tabular}{llll}
\hline $\begin{array}{l}\text { Core, section, } \\
\text { interval (cm) }\end{array}$ & $\begin{array}{l}\text { Depth } \\
\text { (mbsf) }\end{array}$ & $\delta^{18} \mathrm{O}$ & $\delta^{13} \mathrm{C}$ \\
\hline
\end{tabular}

\section{$107-653 \mathrm{~A}^{-\mathrm{b}}$ (Cont.)}

$8 \mathrm{H}$

$\begin{array}{lrrr}7 \mathrm{H}-7,60 & 60.60 & -0.20 & 0.43 \\ 8 \mathrm{H}-1,122 & 61.72 & 1.72 & 0.89 \\ 8 \mathrm{H}-2,60 & 62.60 & -0.28 & -0.06 \\ 8 \mathrm{H}-2,120 & 63.20 & -1.84 & -1.24 \\ 8 \mathrm{H}-3,60 & 64.10 & 0.67 & 1.48 \\ 8 \mathrm{H}-3,120 & 64.70 & 0.84 & 1.54\end{array}$

$\begin{array}{llll}8 \mathrm{H}-3,120 & 64.70 & 0.84 & 1.54\end{array}$

$\begin{array}{llll}8 \mathrm{H}-4,58 & 65.58 & 0.45 & 0.67 \\ 8 \mathrm{H}-4,120 & 66.20 & 0.05 & 1.07\end{array}$

$\begin{array}{llll}8 \mathrm{H}-5,60 & 67.10 & -2.38 & -0.86\end{array}$

$\begin{array}{lrrr}8 \mathrm{H}-5,118 & 67.68 & -0.34 & 0.22 \\ 8 \mathrm{H}-6,60 & 68.60 & 0.36 & 0.93\end{array}$

$\begin{array}{llll}8 \mathrm{H}-6,120 & 69.20 & 0.32 & 0.64\end{array}$

$\begin{array}{llll}9 \mathrm{H}-1,60 & 70.60 & 0.15 & 0.41\end{array}$

$\begin{array}{llll}9 \mathrm{H}-1,120 & 71.20 & 0.05 & 1.27 \\ 9 \mathrm{H}-2,60 & 72.10 & 0.16 & 1.02\end{array}$

$\begin{array}{llll}9 \mathrm{H}-2,120 & 72.70 & 0.44 & 0.81\end{array}$

$\begin{array}{llll}9 \mathrm{H}-3,60 & 73.60 & 1.13 & 1.29\end{array}$

$\begin{array}{llll}9 \mathrm{H}-3,120 & 74.20 & 0.11 & 1.65\end{array}$

$\begin{array}{llll}9 \mathrm{H}-4,60 & 75.10 & 1.31 & 1.46\end{array}$

$\begin{array}{llll}9 \mathrm{H}-4,120 & 75.70 & 1.78 & 0.85\end{array}$

$\begin{array}{llll}9 \mathrm{H}-5,60 & 76.60 & 0.34 & 1.25 \\ 9 \mathrm{H}-5,120 & 77.20 & 1.03 & 0.71\end{array}$

$\begin{array}{llll}9 \mathrm{H}-5,120 & 77.20 & 1.03 & 0.71 \\ 9 \mathrm{H}-6,60 & 78.10 & 1.11 & 1.31\end{array}$

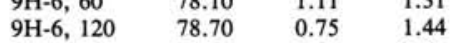

$\begin{array}{llll}9 \mathrm{H}-7,60 & 79.60 & 0.07 & 0.83\end{array}$

$\begin{array}{llll}10 \mathrm{H}-1,60 & 80.20 & 1.83 & 1.33 \\ 10 \mathrm{H}-1,120 & 80.80 & 0.26 & 0.54\end{array}$

$\begin{array}{llll}10 \mathrm{H}-1,120 & 80.80 & 0.26 & 0.54 \\ 10 \mathrm{H}-2,60 & 81.70 & 1.57 & 1.02\end{array}$

$\begin{array}{llll}10 \mathrm{H}-2,120 & 82.30 & 1.03 & 1.48\end{array}$

$\begin{array}{llll}10 \mathrm{H}-3,60 & 83.20 & 1.06 & 1.28 \\ 10 \mathrm{H}-3,120 & 83.80 & 0.60 & 1.06\end{array}$

$\begin{array}{lrrr}10 \mathrm{H}-3,120 & 83.80 & 0.60 & 1.06 \\ 10 \mathrm{H}-4,60 & 84.70 & -0.36 & 1.24\end{array}$

$\begin{array}{llll}10 \mathrm{H}-4,120 & 85.30 & 0.14 & 1.21\end{array}$

$\begin{array}{llll}10 \mathrm{H}-5,60 & 86.20 & -0.24 & 0.23\end{array}$

$\begin{array}{llll}10 \mathrm{H}-5,120 & 86.80 & -0.54 & 0.26 \\ 10 \mathrm{H}-6,60 & 87.70 & -0.01 & 1.05\end{array}$

$\begin{array}{llll}10 \mathrm{H}-6,60 & 87.70 & -0.01 & 1.05 \\ 10 \mathrm{H}-6,120 & 88.30 & -0.04 & 0.68\end{array}$

$\begin{array}{lrrr}10 \mathrm{H}-6,120 & 88.30 & -0.04 & 0.68 \\ 11 \mathrm{H}-1,60 & 89.60 & 0.31 & 0.90\end{array}$

$\begin{array}{llrr}11 \mathrm{H}-1,120 & 90.20 & -1.09 & -0.27\end{array}$

$\begin{array}{llll}11 \mathrm{H}-2,60 & 91.10 & 0.54 & 0.69 \\ 11 \mathrm{H}-2,120 & 91.70 & 0.15 & 0.67\end{array}$

$\begin{array}{llll}11 \mathrm{H}-2,120 & 91.70 & 0.15 & 0.67 \\ 11 \mathrm{H}-3,56 & 92.56 & 0.11 & 0.75\end{array}$

$\begin{array}{llll}11 \mathrm{H}-3,120 & 93.20 & 0.21 & 1.27\end{array}$

$\begin{array}{llll}11 \mathrm{H}-4,56 & 94.06 & -0.10 & 1.28\end{array}$

$\begin{array}{llll}11 \mathrm{H}-4,120 & 94.70 & 0.67 & 1.62\end{array}$

$\begin{array}{llll}11 \mathrm{H}-5,56 & 95.56 & -1.08 & 1.48\end{array}$

$\begin{array}{llll}11 \mathrm{H}-5,120 & 96.20 & -0.43 & 1.34\end{array}$

$\begin{array}{llll}11 \mathrm{H}-6,56 & 97.06 & -0.13 & 1.04 \\ 11 \mathrm{H}-6,120 & 97.70 & -0.32 & 0.92\end{array}$

$\begin{array}{llll}12 \mathrm{H}-1,60 & 98.80 & -0.71 & 1.04\end{array}$

$\begin{array}{llll}12 \mathrm{H}-1,124 & 99.44 & 0.90 & 0.89\end{array}$

$\begin{array}{llll}12 \mathrm{H}-2,60 & 100.30 & -1.27 & 1.20\end{array}$

$\begin{array}{llll}12 \mathrm{H}-2,119 & 100.89 & -0.72 & 0.59\end{array}$

$\begin{array}{llll}12 \mathrm{H}-3,60 & 101.80 & -1.18 & 0.34\end{array}$

$\begin{array}{llll}12 \mathrm{H}-4,60 & 103.30 & -0.66 & 0.17\end{array}$

$\begin{array}{llll}12 \mathrm{H}-4,120 & 103.90 & -1.07 & 0.78 \\ 12 \mathrm{H}-5,60 & 104.80 & -0.34 & 0.82\end{array}$

$\begin{array}{llll}12 \mathrm{H}-5,120 & 105.40 & -1.10 & 1.20\end{array}$

$\begin{array}{llll}12 \mathrm{H}-6,60 & 106.30 & -1.32 & 1.19\end{array}$

$13 \mathrm{H}-1,120 \quad 108.90 \quad-1.15 \quad 0.81$

$\begin{array}{llll}13 \mathrm{H}-2,60 & 109.80 & 1.49 & 1.27\end{array}$

$\begin{array}{llrl}13 \mathrm{H}-2,120 & 110.40 & -0.14 & 1.03 \\ 13 \mathrm{H}-3,58 & 111.28 & 1.03 & 1.26\end{array}$

$\begin{array}{llll}13 \mathrm{H}-3,120 & 111.90 & 0.21 & 0.60\end{array}$

$\begin{array}{llll}13 \mathrm{H}-4,58 & 112.78 & -0.10 & 1.18\end{array}$

$\begin{array}{llll}13 \mathrm{H}-4,120 & 113.40 & 0.15 & 1.31\end{array}$

$\begin{array}{llll}13 \mathrm{H}-5,58 & 114.28 & 0.59 & 1.49\end{array}$

$\begin{array}{llll}13 \mathrm{H}-5,120 & 114.90 & 0.15 & 1.77\end{array}$

$\begin{array}{llll}13 \mathrm{H}-6,58 & 115.78 & -0.25 & 1.04\end{array}$

$\begin{array}{llll}13 \mathrm{X}-6,120 & 116.40 & -0.25 & 0.61\end{array}$

$14 \mathrm{X}-1,60 \quad 117.90 \quad-0.01$

$14 \mathrm{X}-1,120 \quad 118.50 \quad-0.02 \quad 1.23$

$\begin{array}{llrl}14 X-2,60 & 119.40 & -0.51 & 0.65 \\ 14 X-2,120 & 120.00 & 0.07 & 1.39\end{array}$

$\begin{array}{llll}14 \mathrm{X}-3,60 & 120.90 & -0.01 & 1.12\end{array}$

$\begin{array}{llrl}14 \mathrm{X}-3,120 & 121.50 & 0.45 & 1.31\end{array}$
Table 2 (continued).

\begin{tabular}{llll}
\hline $\begin{array}{l}\text { Core, section, } \\
\text { interval (cm) }\end{array}$ & $\begin{array}{l}\text { Depth } \\
\text { (mbsf) }\end{array}$ & $\delta^{18} \mathrm{O}$ & $\delta^{1}$ \\
\hline $107-653 \mathrm{~A}^{\mathrm{b}}$ (Cont.) & &
\end{tabular}

$107-653 \mathrm{~A}^{\mathrm{b}}$ (Cont.)

$\begin{array}{lrrr}14 X-4,60 & 122.40 & -0.24 & 0.80 \\ 14 X-4,120 & 123.00 & -0.98 & 0.59 \\ 14 X-5,60 & 123.90 & -0.60 & 0.69 \\ 14 X-5,120 & 124.50 & -1.36 & 1.02 \\ 14 X-6,60 & 125.40 & -1.08 & 0.71 \\ 14 X-6,120 & 126.00 & 0.14 & 1.34 \\ 15 X-1,60 & 127.20 & 0.07 & 1.26 \\ 15 X-1,120 & 127.80 & -0.58 & 0.70 \\ 15 X-2,60 & 128.70 & 0.28 & 1.37\end{array}$

$\begin{array}{llll}15 X-2,120 & 129.30 & -0.17 & 1.13\end{array}$

$\begin{array}{llll}16 \mathrm{X}-1,60 & 136.70 & 0.02 & 1.02\end{array}$

$\begin{array}{llll}16 \mathrm{X}-1,120 & 137.30 & -0.14 & 0.58\end{array}$

$\begin{array}{llll}16 \mathrm{X}-2,60 & 138.20 & 0.68 & 0.74\end{array}$

$\begin{array}{llll}16 \mathrm{X}-2,120 & 138.80 & 0.59 & 0.55\end{array}$

$\begin{array}{llll}16 \mathrm{X}-3,60 & 139.70 & -0.22 & 0.33 \\ 16 \mathrm{X}-3,120 & 140.30 & -0.14 & 0.77\end{array}$

$\begin{array}{llll}16 \mathrm{X}-3,120 & 140.30 & -0.14 & 0.77 \\ 16 \mathrm{X}-4.60 & 141.20 & -1.51 & 0.16\end{array}$

$16 \mathrm{X}-4,120 \quad 141.80 \quad-1.27 \quad 1.01$

$\begin{array}{llll}16 \mathrm{X}-5,60 & 142.70 & -0.10 & 1.15\end{array}$

$\begin{array}{llll}16 \mathrm{X}-5,118 & 143.28 & -1.70 & 1.10\end{array}$

$\begin{array}{llll}16 \mathrm{X}-6,60 & 144.20 & -0.85 & 0.83\end{array}$

$\begin{array}{llll}17 \mathrm{X}-1,60 & 146.20 & -0.44 & 1.43\end{array}$

$17 \mathrm{X}-1,120 \quad 146.80 \quad-1.54 \quad 0.36$

$\begin{array}{llll}17 X-2,60 & 147.70 & -0.94 & 1.53 \\ 17 X-2,120 & 148.30 & -0.45 & 1.46\end{array}$

$\begin{array}{llll}17 \mathrm{X}-3,60 & 149.20 & -1.85 & 0.62\end{array}$

$\begin{array}{llll}17 X-3,120 & 149.80 & 0.57 & 1.21\end{array}$

$\begin{array}{llll}17 \mathrm{X}-4,120 & 151.30 & -1.34 & 0.68\end{array}$

$\begin{array}{llll}17 X-5,60 & 152.20 & -1.21 & 0.22\end{array}$

$\begin{array}{llll}17 X-5,120 & 152.80 & 0.03 & 1.09\end{array}$

$\begin{array}{llll}17 X-6,60 & 153.70 & -1.26 & 0.51\end{array}$

$\begin{array}{llll}18 \mathrm{X}-1,60 & 155.80 & -1.96 & 0.22\end{array}$

$\begin{array}{llll}18 X-1,120 & 156.40 & -1.37 & 0.42\end{array}$

$18 \mathrm{X}-2,120 \quad 157.90 \quad-1.03 \quad 1.01$

$\begin{array}{llll}18 \mathrm{X}-3,60 & 158.80 & -0.90 & 0.86\end{array}$

$\begin{array}{llll}18 X-3,120 & 159.40 & -1.79 & 0.91\end{array}$

$\begin{array}{llll}18 \mathrm{X}-4,60 & 160.30 & -1.24 & 1.30\end{array}$

$\begin{array}{llll}18 X-4,120 & 160.90 & -0.64 & 0.96\end{array}$

$\begin{array}{llll}18 \mathrm{X}-5,60 & 161.80 & -1.88 & 0.98\end{array}$

$\begin{array}{llll}18 X-5,120 & 162.40 & -0.74 & 1.29\end{array}$

$\begin{array}{llll}18 X-6,60 & 163.30 & -0.65 & 1.38\end{array}$

$\begin{array}{llll}19 \mathrm{X}-1,60 & 164.70 & -1.26 & 1.16\end{array}$

$\begin{array}{llll}19 \mathrm{X}-1,120 & 165.30 & -0.12 & 1.61\end{array}$

$\begin{array}{llll}19 X-2,60 & 166.20 & 0.04 & 0.68\end{array}$

$\begin{array}{llll}19 X-2,120 & 166.80 & -1.71 & 0.45\end{array}$

$\begin{array}{llll}19 X-3,63 & 167.73 & -0.99 & -0.63\end{array}$

$\begin{array}{llll}19 X-3,120 & 168.30 & -0.10 & 1.79\end{array}$

$\begin{array}{llll}19 X-4,60 & 169.20 & 0.38 & 2.11\end{array}$

$\begin{array}{llll}19 X-5,60 & 170.70 & -0.29 & 1.25\end{array}$

$\begin{array}{llll}19 \mathrm{X}-5,120 & 171.30 & -0.12 & 1.36\end{array}$

$\begin{array}{llll}20 \mathrm{X}-1,60 & 174.30 & -2.36 & 0.76\end{array}$

$20 \mathrm{X}-1,120 \quad 174.90 \quad-1.21 \quad 1.30$

$\begin{array}{llll}20 \mathrm{X}-2,60 & 175.80 & -0.61 & 0.72\end{array}$

$\begin{array}{llll}20 \mathrm{X}-2,120 & 176.40 & -1.82 & 0.16\end{array}$

$\begin{array}{llll}20 \mathrm{X}-3,60 & 177.30 & -0.12 & 0.81\end{array}$

$\begin{array}{llll}20 \mathrm{X}-3,120 & 177.90 & -1.30 & 0.83\end{array}$

$\begin{array}{lrrr}20 \mathrm{X}-4,60 & 178.80 & -0.50 & 0.64 \\ 20 \mathrm{X}-4,120 & 179.40 & 0.08 & 0.92\end{array}$

$\begin{array}{lrrr}20 \mathrm{X}-4,120 & 179.40 & 0.08 & 0.92 \\ 20 \mathrm{X}-5,60 & 180.30 & -0.62 & 0.28\end{array}$

$\begin{array}{llll}20 \mathrm{X}-5,120 & 180.90 & 0.03 & 0.74\end{array}$

$\begin{array}{llll}21 \mathrm{X}-1,60 & 183.80 & 0.58 & 1.51\end{array}$

$\begin{array}{llll}21 X-1,120 & 184.40 & -1.48 & 1.34\end{array}$

$\begin{array}{llll}21 \mathrm{X}-2,120 & 185.90 & -0.90 & 1.04\end{array}$

$\begin{array}{llll}21 X-3,60 & 186.80 & 0.19 & 1.24\end{array}$

$\begin{array}{llll}21 X-3,120 & 187.40 & 0.15 & 1.54\end{array}$

$\begin{array}{llll}21 \times-4,60 & 188.30 & -1.00 & -0.08\end{array}$

$21 \mathrm{X}-4,120 \quad 188.90 \quad-0.24 \quad 0.86$

$\begin{array}{llll}21 X-5,60 & 189.80 & -1.26 & 0.45\end{array}$

$\begin{array}{llll}21 X-5,120 & 190.40 & -1.07 & 0.48\end{array}$

$\begin{array}{llll}22 \mathrm{X}-1,60 & 193.50 & 0.38 & 1.34\end{array}$

$\begin{array}{llll}22 \mathrm{X}-1,120 & 194.10 & -0.80 & 0.92\end{array}$

$\begin{array}{llll}22 \mathrm{X}-2,60 & 195.00 & -0.31 & 1.18\end{array}$

$22 \mathrm{X}-2,120 \quad 195.60 \quad-1.45 \quad 1.30$

$\begin{array}{llll}22 \mathrm{X}-3,60 & 196.50 & -1.49 & 1.00\end{array}$

$\begin{array}{llll}22 \mathrm{X}-3,120 & 197.10 & -1.52 & 0.13\end{array}$ 
Table 2 (continued).

\begin{tabular}{|c|c|c|c|}
\hline $\begin{array}{l}\text { Core, section, } \\
\text { interval }(\mathrm{cm})\end{array}$ & $\begin{array}{l}\text { Depth } \\
\text { (mbsf) }\end{array}$ & $\delta^{18} \mathrm{O}$ & $\delta^{13} C$ \\
\hline \multicolumn{4}{|c|}{$107-653 \mathrm{~A}^{-\mathrm{b}}$ (Cont.) } \\
\hline $22 X-4,64$ & 198.04 & -0.60 & \\
\hline $22 \mathrm{X}-4,120$ & 198.60 & -1.05 & \\
\hline $23 \mathrm{X}-1,25$ & 202.65 & 0.26 & \\
\hline $23 \mathrm{X}-1,60$ & 203.00 & -0.26 & \\
\hline $23 \mathrm{X}-1,100$ & 203.40 & 0.24 & \\
\hline $23 \mathrm{X}-1,120$ & 203.60 & 0.07 & \\
\hline $23 \mathrm{X}-2,25$ & 204.15 & -0.13 & \\
\hline $23 \mathrm{X}-2,60$ & 204.50 & -0.76 & \\
\hline $23 \mathrm{X}-2,100$ & 204.90 & -0.48 & \\
\hline $23 \mathrm{X}-2,120$ & 205.10 & -0.88 & \\
\hline $23 \mathrm{X}-3,25$ & 205.65 & -0.17 & \\
\hline $23 \mathrm{X}-3,60$ & 206.00 & -0.58 & \\
\hline $23 \mathrm{X}-3,100$ & 206.40 & -0.23 & \\
\hline $23 \mathrm{X}-3,120$ & 206.60 & -0.74 & \\
\hline $23 \mathrm{X}-4,25$ & 207.15 & -0.55 & \\
\hline $23 X-4,60$ & 207.50 & -0.47 & \\
\hline $23 X-4,100$ & 207.90 & -0.86 & \\
\hline $23 \mathrm{X}-4,120$ & 208.10 & -2.47 & \\
\hline $23 \times-55$ & 208. & -1.05 & \\
\hline $23 X-5,60$ & 209.00 & -1.07 & . \\
\hline $23 X-5,100$ & 209.40 & -1.87 & \\
\hline $23 X-5,120$ & 209.60 & -0.26 & 1. \\
\hline $23 \mathrm{X}-6,25$ & 210.15 & -0.88 & \\
\hline $23 \mathrm{X}-6,60$ & 210.50 & -1.31 & \\
\hline $23 \mathrm{X}-6,100$ & 210.90 & -0.01 & \\
\hline $23 \mathrm{X}-6,120$ & 211.10 & -1.17 & \\
\hline $23 X-7,25$ & 211.65 & -2.05 & -1 . \\
\hline
\end{tabular}

$107-653 \mathrm{~B}-{ }^{b}$

\begin{tabular}{lrrr}
$23 X-1,15$ & 206.85 & -0.72 & 1.31 \\
$23 X-1,25$ & 206.95 & -1.08 & 1.32 \\
$23 X-1,60$ & 207.30 & -0.77 & 0.92 \\
$23 X-1,75$ & 207.45 & 0.25 & 2.38 \\
$23 X-1,120$ & 207.90 & -0.02 & 0.05 \\
$23 X-1,146$ & 208.16 & -0.72 & 1.43 \\
$23 X-2,15$ & 208.35 & 0.62 & 1.61 \\
$23 X-2,25$ & 208.45 & 0.39 & 0.94 \\
$23 X-2,60$ & 208.80 & -0.68 & 0.94 \\
$23 X-2,75$ & 208.95 & 0.42 & 2.21 \\
$23 X-2,100$ & 209.20 & -0.54 & 2.06 \\
$23 X-2,120$ & 209.40 & -1.07 & 1.32 \\
$23 X-2,146$ & 209.66 & 0.34 & 0.57 \\
$23 X-3,15$ & 209.85 & 0.09 & 0.46 \\
$23 X-3,25$ & 209.95 & -0.66 & 1.17 \\
$23 X-3,60$ & 210.30 & -0.57 & 0.61 \\
$23 X-3,75$ & 210.45 & 0.59 & 1.14 \\
$23 X-3,100$ & 210.70 & 0.22 & 1.37 \\
$23 X-3,120$ & 210.90 & -1.30 & 0.99 \\
$23 X-4,15$ & 211.35 & -0.44 & 1.3 \\
$23 X-4,25$ & 211.45 & 0.36 & 1.54 \\
$23 X-4,60$ & 211.80 & -0.64 & 1.29 \\
$23 X-4,75$ & 211.95 & -0.05 & 1.14 \\
$23 X-4,100$ & 212.20 & 1.07 & 1.87 \\
$23 X-4,120$ & 212.40 & -0.82 & 1.55 \\
$23 X-4,146$ & 212.66 & -1.42 & 0.96 \\
$23 X-5,15$ & 212.85 & 0.07 & 1.05 \\
$23 X-5,25$ & 212.95 & -1.64 & 1.65 \\
$23 X-5,60$ & 213.30 & -1.00 & 0.49 \\
$23 X-5,75$ & 213.45 & -1.58 & 1.28 \\
\hline & & &
\end{tabular}

${ }^{a}$ Data from $G$. bulloides.

${ }^{b}$ Data from $O$. universa.

5. Pleistocene sapropels (indicated by "S" in Fig. 2) are marked by anomalously low $\delta^{18} \mathrm{O}$ values $(-0.5 \% 0$ to $-2.4 \% 0)$.

6. A $2.5 \%$ enrichment centered at approximately $17 \mathrm{~m}$ (upper Pleistocene) results in another shift to heavier glacial values. The glacial/interglacial $\delta^{18} \mathrm{O}$ amplitude in this interval is approximately $2.5 \%$.

The major features of the Pliocene-Pleistocene $\delta^{13} \mathrm{C}$ record for Site 653 (Fig. 2) are as follows:
1. The entire record is marked by considerable amplitude variability, but no distinctive long-term change. A possible exception to this observation is the slight trend to heavier values in the upper $50 \mathrm{~m}$.

2. Sapropels are typically characterized by low $\delta^{13} \mathrm{C}$ values $(-1.0 \% 0)$.

\section{DISCUSSION}

In order to facilitate a discussion of the data in terms of the Pliocene-Pleistocene paleoenvironmental history of the Mediterranean, the isotope records have been plotted with respect to time (Fig. 3) using the biostratigraphic datum levels and ages listed in Table 1. Data from the sapropel samples have been eliminated in order to preclude possible distortion of the fundamental patterns. The discussion of the isotope records is presented in chronologic order beginning with the long-term trends and followed by an evaluation of specific time intervals from the earliest Pliocene through the late Pleistocene.

\section{Long-Term Trends in Oxygen and Carbon Isotopes}

The most distinctive feature of the Site $653 \delta^{18} \mathrm{O}$ record is the long-term trend to heavier values with decreasing age, over the last 2.5 Ma (Fig. 3). This pattern has been previously recognized in Mediterranean oxygen isotope records (Keigwin and Thunell, 1979; Thunell and Williams, 1983a). A comparison of a smoothed Site 653 record with that for DSDP Site 132 reveals very strong similarities in both large and small scale features (Fig. 4). In both Site 132 and Site 653 there is an enrichment of about $2.5 \%$ from the basal Pliocene to the upper Pleistocene. This trend is not unique to the Mediterranean, but rather reflects global climatic change that has been reported from all of the major ocean basins (Shackleton and Opdyke, 1977; Keigwin, 1979, 1982 and 1987; Shackleton and Cita, 1979; Prell, 1982; Shackleton et al., 1984; Ruddiman et al., 1987). The long-term trend to heavier $\delta^{18} \mathrm{O}$ values, particularly above $2.5 \mathrm{Ma}$, can be attributed to periodic increases in the size of Northern Hemisphere ice sheets.

The $\delta^{13} \mathrm{C}$ of $O$. universa (Figs. 2 and 3 ) is considered to be a measure of the $\mathrm{\Sigma CO}_{2}$ of near-surface waters (Williams et al., 1977; Berger et al., 1978; Shackleton and Vincent, 1978). Analyses of $O$. universa (350-400 $\mu \mathrm{m}$ size fraction) from western Mediterranean plankton tows (upper $200 \mathrm{~m}$ ) and surface sediments yield an average $\delta^{13} \mathrm{C}$ of $1.42 \%$ (Table 3 ). This value is in good agreement with the value of $1.5 \%$ obtained for the $\mathrm{\Sigma CO}_{2}$ of western Mediterranean surface waters (Duplessy, 1972) which is controlled by the carbon isotopic composition of surface waters entering the Mediterranean from the Atlantic. The modern Mediterranean is somewhat unique in that there is virtually no surface-to-bottom $\delta^{13} \mathrm{C}$ gradient (Duplessy, 1972; Vergnaud-Grazzini, 1983). This is due to the fact that Mediterranean bottom waters are derived from Mediterranean surface waters, and that the residence time of these bottom waters is relatively short (approximately 100 years; Lacombe et al., 1981). The short residence time combined with the oligotrophic nature of Mediterranean surface waters, prevents Mediterranean deep waters from becoming enriched in ${ }^{13} \mathrm{C}$-depleted $\mathrm{CO}_{2}$. In contrast, the adjacent North Atlantic presently has a surface to bottom $\delta^{13} \mathrm{C}$ gradient of about $1.0 \%$ (Kroopnick, 1985).

The Pliocene-Pleistocene $\delta^{13} \mathrm{C}$ record for Site 653 is characterized by fairly large amplitude oscillations, with values primarily fluctuating between 0.0 and $1.5 \%$ (Fig. 3). The upper end of this range corresponds to the present day $\delta^{13} \mathrm{C}$ value of western Mediterranean surface waters (Duplessy, 1972), indicating that in the past surface waters were commonly much lighter than at present. The variability in $\delta^{13} \mathrm{C}$ through time at Site 653 may document changes in the carbon isotopic composition of North Atlantic surface waters that enter the Mediterranean, or 

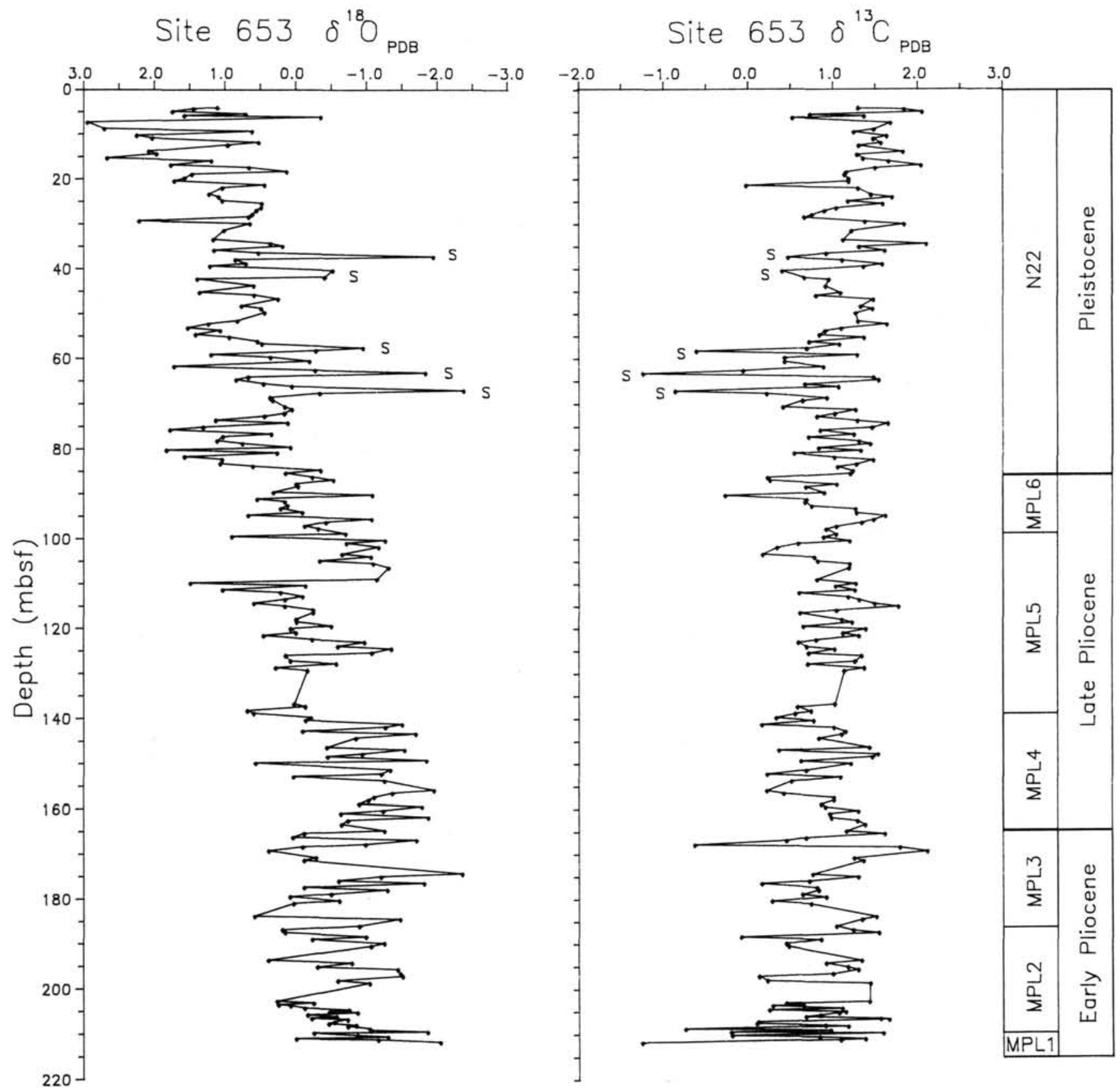

Figure 2. Site 653 oxygen and carbon isotopic data for the planktonic foraminifer Orbulina universa plotted vs. depth. The position of sapropel samples are indicated by an "S." All data are listed in Table 2.

it may reflect a more fundamental change in the pattern of water exchange between the Mediterranean and the Atlantic (Thunell et al., 1987). In the latter situation, there may have been times during the Pliocene-Pleistocene when the Mediterranean had a positive water budget (inflow at depth and outflow at the surface).

\section{The Basal Pliocene-Restoration of Open Marine Conditions}

The sharp lithologic contact between Messinian evaporites and Zanclean deep-sea marls that typifies the Miocene/Pliocene boundary in the Mediterranean region is an obvious consequence of a sudden and major change in paleoenvironmental conditions. The isolation and desiccation of the Mediterranean during latest Miocene time and the resultant accumulation of massive evaporite deposits are topics that have generated a great deal of interest and controversy (Cita and Ryan, 1973; Adams et al., 1977; Hsü et al., 1977; Van Couvering et al., 1976; among others). An equally intriguing and important problem is the restoration of open marine conditions in the Mediterranean at the beginning of the Pliocene. Unfortunately, most lower Pliocene (biozone MPL1 of Cita, 1975) stratigraphic sequences from the Mediterranean, both on land and from the deep sea, are marked by a hiatus with the basal Pliocene being absent (Sprovieri, 1976).

The Site 653 sedimentary sequence appears to contain a relatively complete MPL1 interval and should provide insight into the paleoenvironment that existed as marine conditions were reestablished in the Mediterranean. Oxygen and carbon isotopes, carbonate accumulation rates and benthic foraminiferal number (number of benthic foraminifers per gram of sediment) are used 


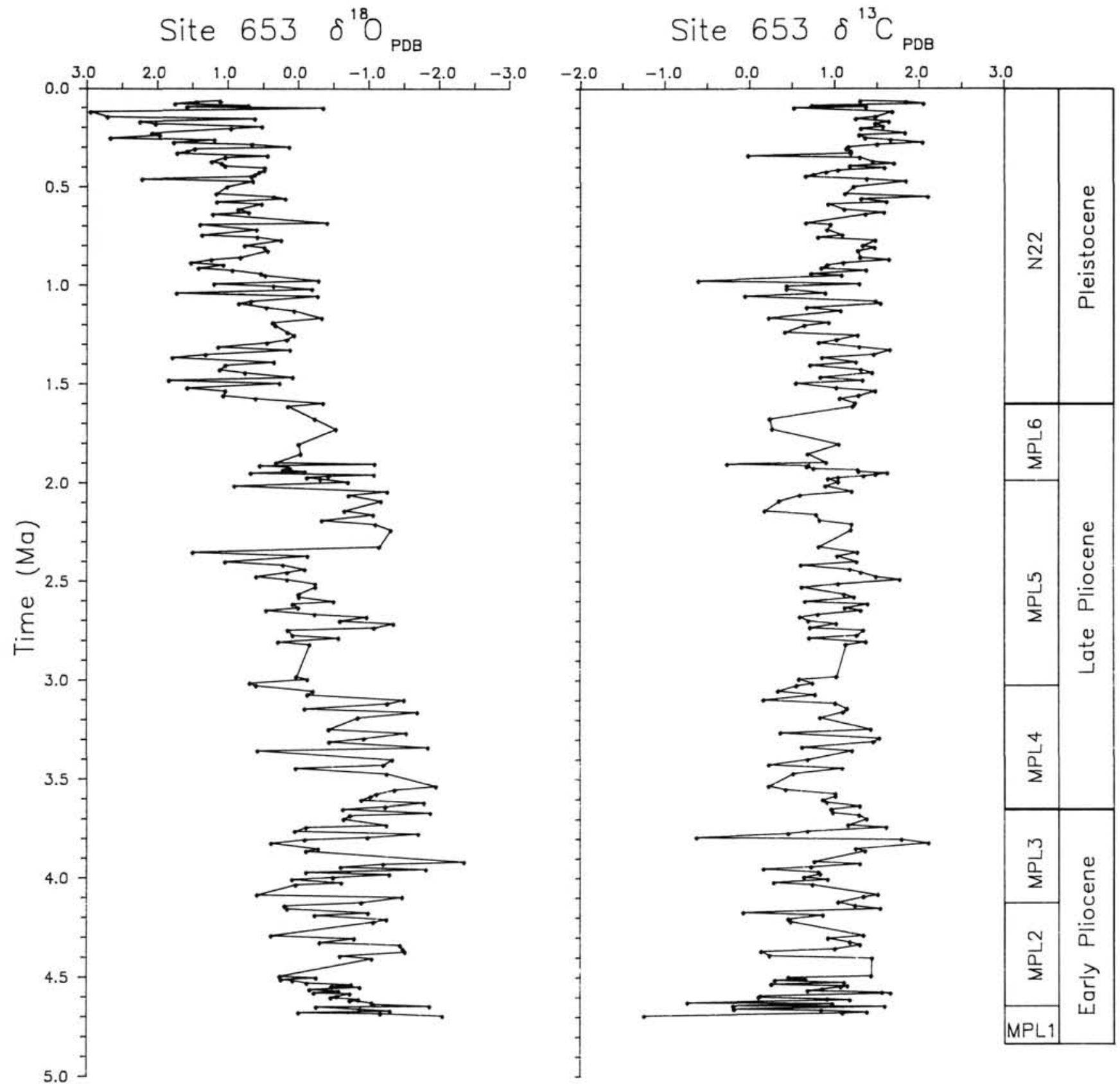

Figure 3. Site 653 oxygen and carbon isotopic data for Orbulina universa plotted vs. time. The time scale is based on the biochronology given in Table 1. Data for the sapropel samples have been eliminated from this plot in order to remove the effect of anomalously light values on the overall pattern of the oxygen and carbon records.

to assess paleoenvironmental conditions during the earliest Pliocene (Fig. 5). Each of these indices shows some distinctive differences between biozones MPL1 and MPL2. The number of benthic foraminifers greater than $150 \mu \mathrm{m}$ is uniformly low throughout MPL1 (average of less than 15 specimens per gram of sediment), and increases considerably in MPL2 (average of 60 specimens per gram of sediment). In contrast, the number of benthic foraminifers in the $63-150 \mu \mathrm{m}$ size fraction is variable but generally rather high in MPL1 (average of 620 specimens per gram), and then decreases somewhat in MPL2 (average of 440 specimens per gram). The high number of small benthic foraminifers and low number of large benthic foraminifers during MPL1 may be indicative of a highly stressed environment. According to Boltovskoy and Wright (1976), an assemblage dominated by small individuals is the result of environmental conditions approaching the tolerance limits of the population. More specifically, the low numbers of large benthic foraminifers during MPL1 may be due to low levels of surface productivity which resulted in a low flux of organic matter to the seafloor and a low standing stock of benthic foraminifers. This interpretation seems to be supported by the carbonate accumulation record which is uniformly low $\left(1.9 \mathrm{gm} / \mathrm{cm}^{2} / 1000 \mathrm{yr}\right)$ during MPL1 and increases to $3.2 \mathrm{gm} / \mathrm{cm}^{2} / 1000 \mathrm{yr}$ during MPL2 (Fig. 5). The calculation of carbonate accumulation rates removes the effect of variation in non-calcareous input, and therefore the change in carbonate accumulation between MPL1 and MPL2 cannot be attributed to dilution. The carbonate accumulation record is interpreted here as indicating that productivity was low during. 


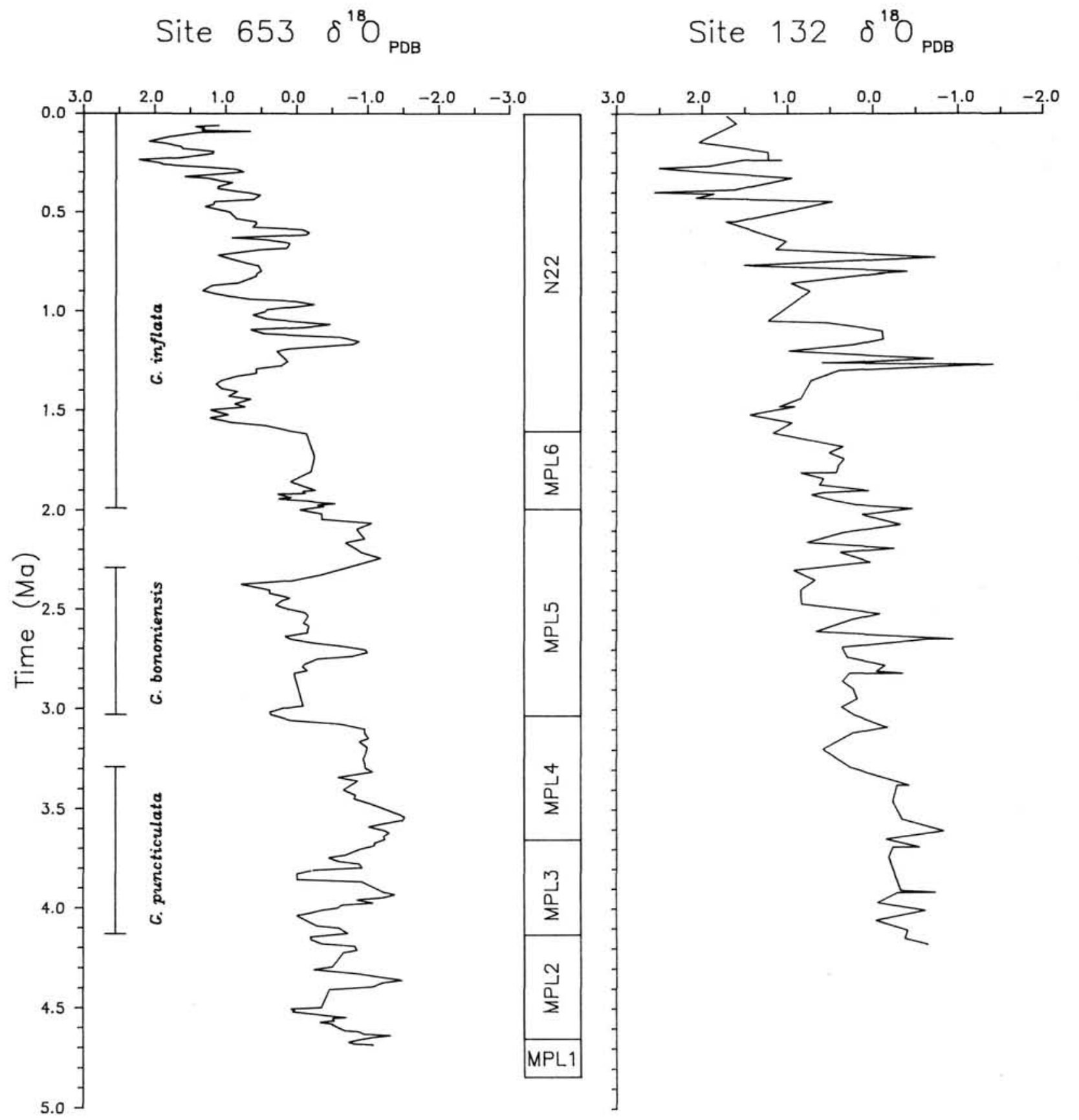

Figure 4. Comparison of ODP Site 653 and DSDP Site 132 oxygen isotope records. The Site 653 record has been smoothed using a threepoint running average to facilitate easier correlation with the Site 132 record which has a much larger sampling interval. The Site 132 record is from Thunell and Williams (1983a). The stratigraphic distribution of the three members of the Globorotalia inflata group (G. puncticulata, G. bononiensis, and $G$. inflata) in Site 653 is indicated.

MPL1 and increased during MPL2. An alternative explanation would be that the higher carbonate accumulation rates during MPL2 were due to increased input of allochthonous carbonate detritus.

The carbon isotope record is relatively stable during MPL1 (average value of $1.25 \%$; Fig. 5). This stability probably reflects a uniform source for Mediterranean surface waters during this period. Within MPL2, the $\delta^{13} \mathrm{C}$ record becomes more variable and the values are, on average, somewhat lighter. The difference in the character of the $\delta^{13} \mathrm{C}$ record between MPL1 and MPL2 may also be indicative of productivity differences. The relatively stable $\delta^{13} \mathrm{C}$ record during MPL1 may be due to a consistent in- put of nutrient-depleted waters from the Atlantic, which in turn would result in low levels of productivity in the Mediterranean. The more variable nature of the MPL2 $\delta^{13} \mathrm{C}$ record may be a function of alternating input of nutrient-rich and nutrient-depleted Atlantic waters, which would at least periodically result in higher levels of productivity. This increased productivity would have resulted in higher carbonate accumulation rates and a higher standing stock of benthic foraminifers.

\section{Early Pliocene (MPL2-MPL3)-Stable Climate?}

The oxygen isotope results for Site 653 indicate highly variable conditions in the Tyrrhenian Sea during much of the early 
Table 3. Stable isotopic data for Orbulina universa from plankton tows and core top samples from the western Mediterranean.

\begin{tabular}{lrlrr}
\hline Sample & Latitude & Longitude & $\delta^{18} \mathrm{O}$ & $\delta^{13} \mathrm{C}$ \\
\hline \multicolumn{4}{l}{ Plankton tow samples ${ }^{\mathrm{a}}$ : } \\
\multicolumn{4}{l}{} \\
1 & $37^{\circ} 57^{\prime} \mathrm{N}$ & $1^{\circ} 57^{\prime} \mathrm{E}$ & 0.45 & 1.76 \\
2 & $37^{\circ} 20^{\prime} \mathrm{N}$ & $0^{\circ} 32^{\prime} \mathrm{E}$ & 0.49 & 1.39 \\
3 & $36^{\circ} 35^{\prime} \mathrm{N}$ & $0^{\circ} 44^{\prime} \mathrm{W}$ & 0.48 & 1.36 \\
4 & $36^{\circ} 25^{\prime} \mathrm{N}$ & $2^{\circ} 28^{\prime} \mathrm{W}$ & -0.39 & 1.55 \\
5 & $41^{\circ} 20^{\prime} \mathrm{N}$ & $7^{\circ} 37^{\prime} \mathrm{E}$ & 0.03 & 1.27
\end{tabular}

Surface sediment samples:

\begin{tabular}{lllll} 
TR171-6 & $38^{\circ} 47^{\prime} \mathrm{N}$ & $4^{\circ} 02^{\prime} \mathrm{E}$ & 1.32 & 1.32 \\
TR171-9 & $38^{\circ} 18^{\prime} \mathrm{N}$ & $9^{\circ} 15^{\prime} \mathrm{E}$ & 1.12 & 1.20 \\
V10-73 & $38^{\circ} 18^{\prime} \mathrm{E}$ & $8^{\circ} 40^{\prime} \mathrm{E}$ & 0.76 & 1.50 \\
\hline
\end{tabular}

${ }^{\text {a }}$ Plankton tow material collected in June 1969 and described by Cifelli (1974).

Pliocene (Fig. 3). In particular, the interval from 4.7 to $3.5 \mathrm{Ma}$ is marked by high amplitude $(1.5 \%)$, quasi-periodic fluctuations in the $\delta^{18} \mathrm{O}$ record (Fig. 6). A similar signal is not seen in the Site $132 \delta^{18} \mathrm{O}$ record (Fig. 4) and may be attributable to two factors. First, the Site 132 record only extends to $4.2 \mathrm{Ma}$, and second, the record for the 4.2 to $3.4 \mathrm{Ma}$ interval of Site 132 has a 50,000-year sample spacing. In comparison, the spacing between samples for the equivalent interval in Site 653 is 12,000 years.

The magnitude of the early Pliocene fluctuations in the Site 653 record are very similar to typical late Pleistocene glacial/interglacial $\delta^{18} \mathrm{O}$ cycles in the Mediterranean. It is difficult to interpret this variability in light of the open-ocean $\delta^{18} \mathrm{O}$ record. While there is evidence for significant ice volume and sea-level changes in the late Miocene (Keigwin et al., 1987), most openocean studies have concluded that the early Pliocene was a time of relatively warm, stable climatic conditions (Keigwin, 1982; Hodell and Kennett, 1986). However, these studies had coarse sample spacing as did studies at DSDP Site 132. Oxygen isotope records for North Atlantic DSDP Sites 552 (Shackleton et al., 1984) and 606 (Keigwin, 1987) show that the early Pliocene is marked by fluctuations of approximately $0.5 \%$. Thus, the $1.5 \%$ changes in $\delta^{18} \mathrm{O}$ observed for Site 653 cannot be readily attributed to ice volume changes. The assumption that at least $1.0 \%$ of this variability is related to temperature would require surface temperature fluctuations of nearly $5^{\circ} \mathrm{C}$ during the early Pliocene. Fluctuations of this magnitude are comparable to previously estimated temperature changes for the last glacial/interglacial transition in the western Mediterranean (Thiede, 1978). Therefore, it would appear that a considerable amount of the variability in the early Pliocene $\delta^{18} \mathrm{O}$ record must be due to salinity changes in the Tyrrennhian Sea.

\section{Mid-Late Pliocene Paleoenvironments (MPL4-MPL6)}

The interval from approximately $3.6 \mathrm{Ma}$ to the Pliocene/ Pleistocene boundary contains a number of very distinctive paleoclimatic or paleoceanographic events (Fig. 3). Most of biozone MPL4 (3.65 to $3.05 \mathrm{Ma}$ ) is characterized by relatively low $\delta^{18} \mathrm{O}$ values (Figs. 3 and 4) which are interpreted as indicating relatively warm surface temperatures. This interpretation is supported by the absence of Globorotalia puncticulata in the upper part of biozone MPL4 (Fig. 4). This species is a member of the Globorotalia inflata lineage ( $G$. puncticulata, $G$. bononiensis, and $G$. inflata) and its presence is considered to reflect cool, temperate conditions (Zachariasse and Spaak, 1983). At approximately $3.1 \mathrm{Ma}$, a rapid $1.5 \%$ enrichment occurs, with values above this level typically being heavier than those below. A similar enrichment has previously been reported for the Mediterranean (Keigwin and Thunell, 1979; Thunell and Williams, 1983a) and the open ocean (Shackleton and Opdyke, 1977; Keigwin, 1982; Hodell et al., 1983; Leonard et al., 1983; Prell, 1984; among others). Most of these studies have concluded that this $\delta^{18} \mathrm{O}$ increase is due primarily to a climatic cooling and not a significant growth of continental ice. Recent planktonic foraminiferal faunal studies in the North Atlantic support this interpretation by documenting a surface water cooling (Ehrmann and Keigwin, 1987) and southward displacement of the North Atlantic Drift (Raymo et al., 1987) at this time.

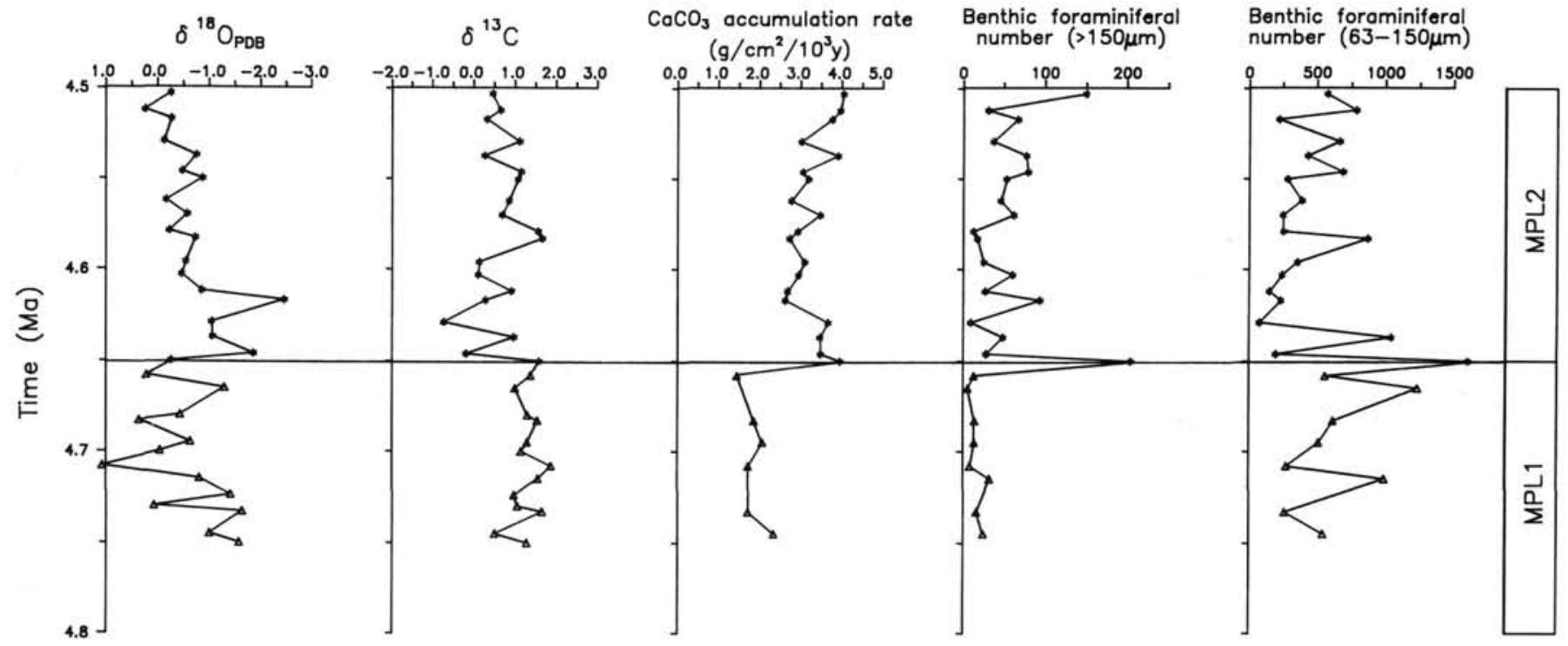

Figure 5. Oxygen and carbon isotopes, carbonate accumulation rate and benthic foraminiferal number for the basal Pliocene (MPL1 and lower MPL2) of Site 653. Samples from Holes 653A and 653B have been combined since Hole 653A did not recover the lowermost part of MPL1. The dots indicate Hole 653A samples and the triangles represent Hole 653B samples. The position of the MPL1-MPL2 boundary (G. margaritae FO) is indicated. 


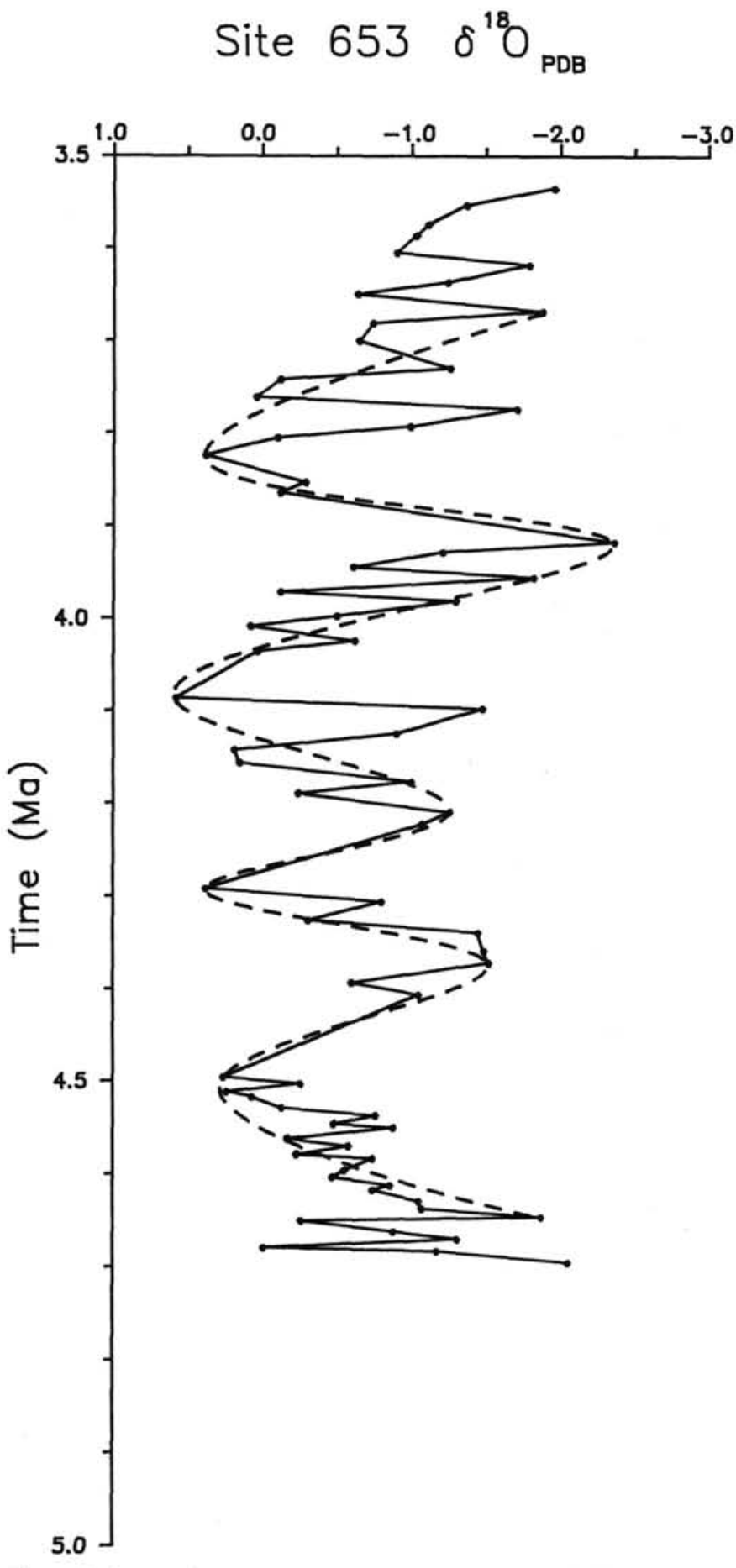

Figure 6. Oxygen isotope record for the early Pliocene (MPL2-MPL3) interval of Site 653. A cubic spline has been run through the data to illustrate the quasi-periodic nature of the $\delta^{18} \mathrm{O}$ oscillations.

Within the Mediterranean, this cooling at approximately 3.1 Ma resulted in a major turnover in both planktonic (Zachariasse and Spaak, 1983) and benthic foraminifers (Sprovieri, 1978; van der Zwaan, 1983). Coincidental with this $3.1 \mathrm{Ma}$ event is the reintroduction of the cool water $G$. inflata group (i.e., G. bononiensis) into the Mediterranean (Fig. 4). Pollen studies of Sicily and southern Italy (Bertoldi et al., in press) indicate that vegetational changes occur synchronously with these foraminiferal faunal changes. The pollen results suggest that a cool, humid climate was established in the south-central Mediterranean at this time.

Two other rapid increases in $\delta^{18} \mathrm{O}$ at approximately 2.7 and $2.1 \mathrm{Ma}$ are separated by an interval of relatively light values from 2.3 to $2.1 \mathrm{Ma}$ (Figs. 3 and 4 ). In our previous isotopic study of Site 132 we reported an abrupt enrichment in $\delta^{18} \mathrm{O}$ at approximately $2.5 \mathrm{Ma}$ (Thunell and Williams, 1983a). Applying the biochronologic scheme of this study (Table 1) to the Site 132 record results in a revised age estimate of approximately $2.6 \mathrm{Ma}$ for this event (Fig. 4). We conclude that the enrichment dated at approximately $2.7 \mathrm{Ma}$ in Site 653 is probably equivalent to the event dated at 2.6 Ma in Site 132 (Fig. 4).

Although these ages are slightly older than the date of 2.5 Ma for the first occurrence of ice-rafted debris in the North Atlantic (Backman, 1979; Shackleton et al., 1984; Ruddiman et al., 1987), we feel that the enrichment event recorded in the Mediterranean at 2.6-2.7 Ma is the result of significant growth of Northern Hemisphere glaciation and that the age discrepancy may be an artifact of the use of different time scales. The climatic cooling associated with this glacial expansion resulted in a southerly migration of the subpolar province down the eastern side of the North Atlantic (Thunell and Belyea, 1982). This migration in turn allowed the introduction of a temperate-subpolar assemblage into the Mediterranean at this time (Ciaranfi and Cita, 1973; Thunell, 1979; Zachariasse and Spaak, 1983).

The relatively light $\delta^{18} \mathrm{O}$ values between 2.3 and $2.1 \mathrm{Ma}$ (Figs. 3 and 4) are interpreted as a warming of Tyrrhenian Sea surface waters, possibly associated with a decrease in Northern Hemisphere ice volume. The benthic isotope record for North Atlantic DSDP Site 552 indicates that following the major buildup of ice between 2.4 and $2.3 \mathrm{Ma}$, a significant decrease in ice volume occurred during the following 200,000 years (Shackleton et al., 1984). The disappearance of the temperate G. bononiensis from the Mediterranean during this time interval is a further indication of surface-water warming (Fig. 4).

The $1.5 \% 0 \delta^{18} \mathrm{O}$ enrichment at approximately $2.1-2.0 \mathrm{Ma}$ (Figs. 3 and 4) is due to an increase in Northern Hemisphere ice volume and a cooling of Mediterranean surface waters. Using the oxygen isotope record from North Atlantic DSDP Site 552 (Shackleton et al., 1984) as an ice-volume indicator, it is evident that a significant glacial advance occurred around 2.1 Ma. Surface-water cooling at this time in the Mediterranean is also reflected in the reintroduction of the $G$. inflata group (Fig. 4). The oxygen isotopic record above $2.1 \mathrm{Ma}$ is characterized by highamplitude $(1.5 \% 0-2.0 \%)$ and high frequency glacial-interglacial oscillations (Fig. 3).

\section{Pliocene/Pleistocene Boundary Event}

The stratigraphic recognition and paleoclimatic significance of the Pliocene/Pleistocene boundary have been topics of considerable debate over the years (see Pelosio et al., 1980 and Rio et al, 1984 for reviews). Hopefully, most of these problems have now been resolved with the general acceptance of the Vrica section (Calabria, southern Italy) as the stratotype for the Pliocene/Pleistocene boundary (Selli et al., 1977; Colalongo et al., 1982; Pasini et al., in press). The boundary marker bed at Vrica has been paleomagnetically dated at 1.6 Ma (Tauxe et al., 1983), with the first appearance of Gephyrocapsa oceanica occurring just above this level (Backman et al., 1983; Rio et al., in press).

In a study of the Le Castella section (Calabria, southern Italy), Emiliani et al. (1961) reported that the Pliocene/Pleistocene boundary was not marked by any distinctive oxygen isotopic signature. However, recent work of Rio et al. (in press) has demonstrated that the boundary marker bed at Le Castella is younger than $1.3 \mathrm{Ma}$, and that a considerable part of the uppermost Pliocene and lowermost Pleistocene is missing from this section. 
The $\delta^{18} \mathrm{O}$ record for Site 653 shows a significant enrichment $(\sim 1.5 \%)$ across the Pliocene/Pleistocene boundary with glacial values above the boundary being significantly heavier than those below (Figs. 3 and 4). A similar feature is also present in the Site $132 \delta^{18} \mathrm{O}$ record (Fig. 4). It is unclear if this climatic change at the Pliocene/Pleistocene boundary is global in nature, or if it is peculiar to the Mediterranean region. According to Pasini et al. (in press) the Pliocene/Pleistocene boundary marker bed at Vrica is "penecontemporaneous to the first appearance of the 'northern guest' Arctica islandica in the Mediterranean." The entry of this boreal, shallow-water mollusk has traditionally been interpreted as representing a climatic cooling in the Mediterranean (see Pelosio et al., 1980 for a review). Thus, at least within the Mediterranean, the Pliocene/Pleistocene boundary is marked by a climatic cooling. This cooling, however, is not to be confused with the climatic deterioration that began nearly near one million years earlier with the growth of the Northern Hemisphere ice sheet and the beginning of glacial/interglacial climatic oscillations.

\section{Isotopic Signature of Pleistocene Sapropels}

Within the Pleistocene $\delta^{18} \mathrm{O}$ record of Site 653 five levels corresponding to sapropels are marked by anomalously light values (Fig. 2). This part of the record, both in terms of stratigraphic position and isotopic signature of the sapropels, is strikingly similar to that previously reported for Site 132 (Thunell and Williams, 1983a) (Fig. 4),

The initial work of Emiliani $(1955,1974)$ clearly demonstrated that the amplitude of the Mediterranean glacial/interglacial $\delta^{18} \mathrm{O}$ signal is considerably larger than that recorded in the open ocean. More recent isotopic studies have demonstrated that at least part of this large-amplitude signal is the result of very light values associated with the formation of sapropels (Thunell et al., 1977, 1983, and 1984; Vergnaud Grazzini et al., 1977 and 1986; Williams et al., 1978; Rossignol-Strick et al., 1982; Ganssen and Troelstra, 1987; among others). These authors are in general agreement that the anomalously light $\delta^{18} \mathrm{O}$ values reflect decreased surface-water salinity due to freshwater input during sapropel formation.

The carbon isotopic composition of specimens of Orbulina universa deposited during sapropel formation is also generally very light (Fig. 2). This association of light planktonic $\delta^{13} \mathrm{C}$ values and sapropels has previously been reported by VergnaudGrazzini et al. (1977, 1986), Thunell and Williams (1983b), Thunell et al. (1983), and Ganssen and Troelstra (1987). The light $\delta^{13} \mathrm{C}$ values can best be explained by the introduction of isotopically light terrestrial organic matter $(-25 \%)$ during sapropel formation. Remineralization of a portion of this organic matter in the upper water column would reduce the $\delta^{13} \mathrm{C}$ of surface waters, and in turn would be recorded by near-surface dwelling planktonic foraminifers. The observed relationship between low $\delta^{13} \mathrm{C}$ values and sapropels argues against the idea that the high organic carbon content of sapropels is due solely to increased surface productivity (Calvert, 1983). Such an increase in primary productivity would enrich surface waters in ${ }^{13} \mathrm{C}$, but such an enrichment is not recorded in the carbon isotopic composition of planktonic foraminifers.

\section{Pleistocene Paleoenvironments}

Several aspects of the Site 653 Pleistocene $\delta^{18} \mathrm{O}$ and $\delta^{13} \mathrm{C}$ records lend themselves to a discussion of: (1) the recognition of oxygen isotope stages in the upper Pleistocene; (2) the shift to heavier glacial $\delta^{18} \mathrm{O}$ values during the last 400,000 years; and (3) the gradual increase in $\delta^{13} \mathrm{C}$ values during the last $1 \mathrm{~m}$.y.

Thierstein et al. (1977) have demonstrated the global synchroneity of several late Pleistocene nannofossil datums and have established the stratigraphic position of these datums with respect to oxygen isotope stratigraphy. These datums include: (1) the last occurrence of Pseudoemiliania lacunosa within glacial stage 12 , approximately 466,000 years ago; (2) the first appearance of Emiliania huxleyi in glacial stage 8, approximately 268,000 years ago; and (3) the reversal in dominance between Gephyrocapsa caribbeanica and E. huxleyi in the upper part of interglacial stage 5, approximately 85,000 years ago. Utilizing these datums, glacial/interglacial oxygen isotopic stages have been preliminarily identified for the last 500,000 years in the Site 653 record (Fig. 7). Recognition of these stages, as defined in the open ocean (Emiliani, 1966; Shackleton and Opdyke, 1973), is not always straightforward in Mediterranean records because of the overprint of local hydrographic conditions on the shape and amplitude of individual stages. For example, the gla$\mathrm{cial} /$ interglacial amplitude in this part of the record is frequently $2.0 \%-3.0 \%$ or more, in comparison to $1.6 \% 0-1.8 \%$ for the open ocean (Broecker, 1986). No attempt has been made to identify stages prior to 500,000 years ago because of distortion

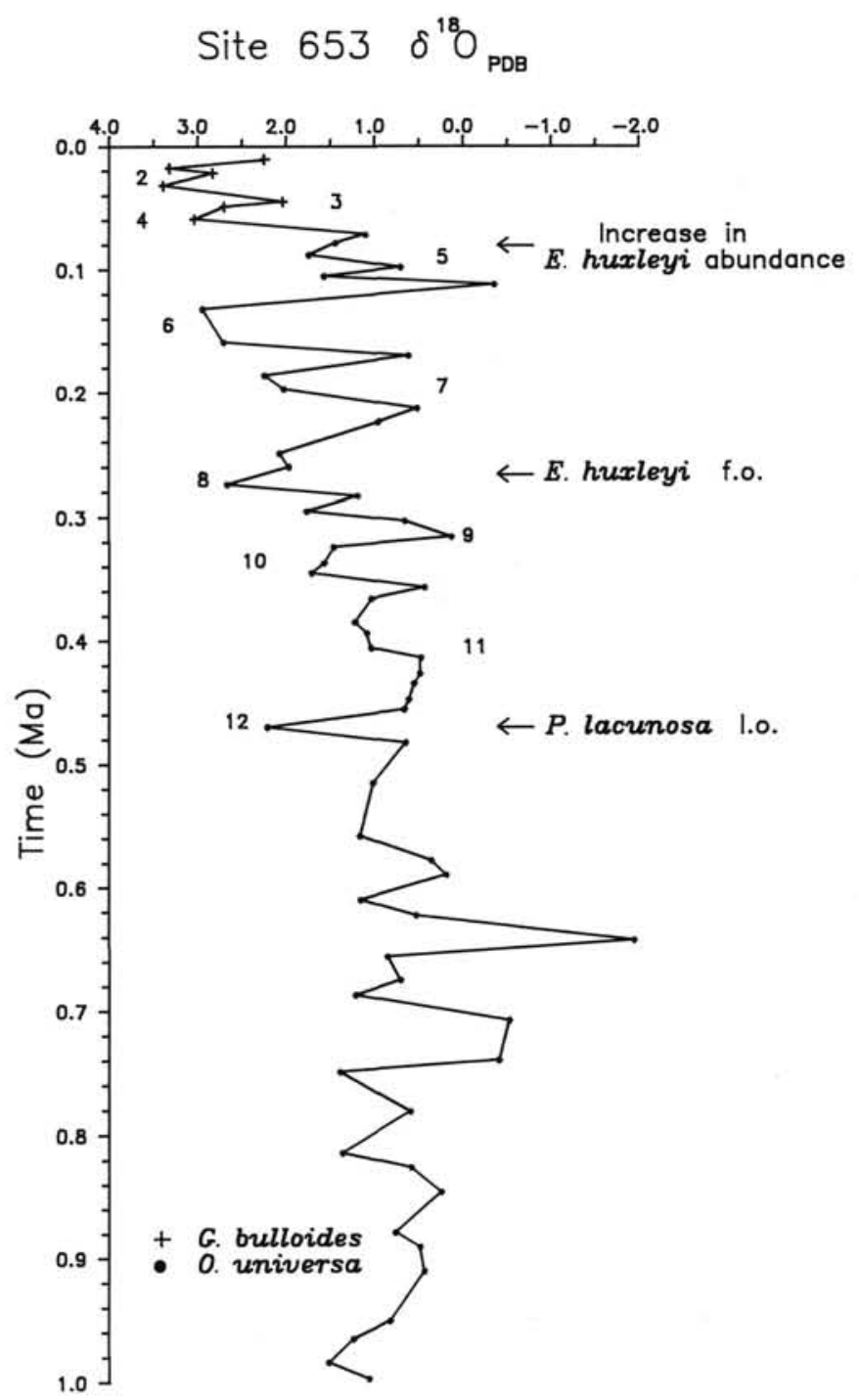

Figure 7. Oxygen isotopic record for the last 1.0 million years at Site 653. The stratigraphic positions of three late Pleistocene nannofossil datums are indicated. Oxygen isotopic stages have been identified for the last 500,000 years using these datums and their established correlation to the oxygen isotope record (Thierstein et al., 1977). 
created by sapropels, inadequate sampling resolution and lack of biostratigraphic check-points.

In the open ocean, there is a distinctive change in the character of the $\delta^{18} \mathrm{O}$ record between 800,000 and 900,000 years ago (Shackleton and Opdyke, 1976; Van Donk, 1976). Prior to this time, the periodicity of glacial/interglacial ice volume change was dominated by the 41,000 -year obliquity cycle, while the 100,000 -year precession cycle dominated late Pleistocene ice-volume change (Pisias and Moore, 1981; Ruddiman et al., 1986). In addition, the amplitude of early Pleistocene ice volume change, as reflected in the $\delta^{18} \mathrm{O}$ record, is smaller than in the late Pleistocene. This is reflected in a shift to larger glacial $\delta^{18} \mathrm{O}$ values beginning with isotope stage 22 (Shackleton and Opdyke, 1976; Ruddiman et al., 1986; Williams et al., 1988).

This intensification of Northern Hemisphere glaciation around 800,000 years ago is not apparent in the Site $653 \delta^{18} \mathrm{O}$ record (Fig. 3). Instead, a general increase in glacial $\delta^{18} \mathrm{O}$ values begins at the level we have identified as glacial stage 12 (Fig. 7). With the exception of stage 10, the glacial stages of the last 460,000 years have maximum values of $2.5 \% 0-3.4 \%$. Although we have not identified individual glacial/interglacial stages below stage 12 , the heaviest values (presumably glacial intervals) between 0.5 and $1.0 \mathrm{Ma}$ are $1.0 \%-1.5 \%$. A similar increase in glacial $\delta^{18} \mathrm{O}$ values $400,000-500,000$ years ago is also evident in the Site 132 record (Fig. 4). Thunell and Williams (1983a) originally considered this event in the Site 132 record to occur in the middle Pleistocene, approximately 900,000 years ago. However, our revised biostratigraphy and the recognition of a significant hiatus in the upper Pleistocene of Site 132 clearly places this event at a much younger age.

Ruddiman and Raymo (1988) have recently demonstrated that the influence of the 100,000-year eccentricity cycle on the earth's climate system became predominant approximately 450,000 years ago. At this time, there was a considerable increase in the amplitude of glacial/interglacial sea surface temperatures in the North Atlantic, with glacial values becoming significantly colder. Ruddiman and Raymo (1988) have speculated that this modification of the climate system was a response to the development of the present-day planetary wave pattern, which in turn was controlled by tectonic uplift of the continents. The Mediterranean seems to have responded to this change in climatic regime around 450,000 years ago in a manner similar to the North Atlantic.

\section{SUMMARY}

The major features of the Pliocene-Pleistocene paleoenvironmental history of the Mediterranean, as deduced from oxygen and carbon isotope records from ODP Site 653, are as follows:

1. A long-term increase of nearly $2.5 \% 0$ occurs in the $\delta^{18} \mathrm{O}$ record from the early Pliocene to the late Pleistocene. Significant enrichments in ${ }^{18} \mathrm{O}$ occur at $3.1,2.7 ., 2.1,1.6$ and $0.4 \mathrm{Ma}$, and are related to decreases in surface water temperature and/or increases in global ice volume.

2. Sedimentological, micropaleontological and geochemical results indicate that productivity was low in the basal Pliocene as open marine conditions were reestablished.

3. Large-amplitude oscillations in the early Pliocene (MPL2 and MPL3) $\delta^{18} \mathrm{O}$ record indicate that climatic conditions in the Mediterranean at this time were quite variable. In contrast, most open-ocean studies have considered the early Pliocene to be a time of very stable climate.

4. A comparison of the stratigraphic distribution of the $G$. inflata group with the $\delta^{18} \mathrm{O}$ record clearly indicates that the presence or absence of the various members of this group is controlled by surface water temperature. The first appearances of $G$. bononiensis and $G$. inflata are associated with coolings, while the last occurrences of $G$. puncticulata and $G$. bononiensis coincide with warmings.

5. A $1.5 \%$ increase in $\delta^{18} \mathrm{O}$ occurs across the Pliocene/Pleistocene boundary. This isotopic event corroborates other evidence that, at least within the Mediterranean region, this boundary is marked by a climatic cooling. The cooling recognized in the $\delta^{18} \mathrm{O}$ record is stratigraphically equivalent to the first appearance of the "northern guest" Arctica islandica in the Mediterranean.

6. Pleistocene sapropels are characterized by very light $\delta^{18} \mathrm{O}$ and $\delta^{13} \mathrm{C}$ values. This isotopic signature reflects decreased surface water salinity and the input of isotopically light terrestrial organic matter.

7. A shift to heavier glacial $\delta^{18} \mathrm{O}$ values occurs between 400,000 and 500,000 years ago. This change in the nature of the late Pleistocene $\delta^{18} \mathrm{O}$ record may be related to an increase in the influence of the 100,000 -year eccentricity cycle on the earth's climate system.

\section{ACKNOWLEDGMENTS}

We thank K. Kastens, L. Keigwin, J. Mascle, F. McCoy and D. Oppo for reviewing the paper. Samples for this study were provided by ODP with assistance from the National Science Foundation. This work was supported by NSF Grant EAR-8506844 to R. Thunell.

\section{REFERENCES}

Adams, C. G., Benson, R. H., Kidd, R. B., Ryan, W.B.F., and Wright, R. C., 1977. The Messinian salinity crisis and evidence of late Miocene eustatic changes in the world ocean. Nature, 269:383-386.

Backman, J., 1979. Pliocene biostratigraphy of DSDP Sites 111 and 116 from the North Atlantic Ocean and age of Northern Hemisphere glaciation. Stockholm Contrib. Geol., 33:115-137.

Backman, J., Shackleton, N. and Tauxe, L., 1983. Quantitative nannofossil correlation to open ocean deep-sea sections from Plio-Pleistocene boundary at Vrica, Italy. Nature, 304:156-158.

Berger, W. H., Killingley, J. S., and Vincent, E., 1978. Stable isotopes in deep-sea carbonates: box core ERDC-92, west equatorial Pacific. Oceanol. Acta, 1:203-216.

Berggren, W. A., Kent, D. V., Flynn, J. J. and Van Couvering, J.A., 1985. Cenozoic geochronology. Geol. Soc. Am. Bull., 96:1407-1418.

Bertoldi, R., Rio, D. and Thunell, R., (in press). Pliocene-Pleistocene vegetational and climatic evolution of the south-central Mediterranean. Paleogeog. Paleoclim. Paleoecol.

Boltovskoy, E. and Wright, R., 1976. Recent Foraminifera. The Hague (W. Junk), p. 515.

Broecker, W. S., 1986. Oxygen isotope constraints on surface ocean temperatures. Quat. Res., 26:121-134.

Buckley, H. A., Johnson, L. R., Shackleton, N. J. and Blow, R. A., 1982. Late glacial to Recent cores from the eastern Mediterranean. Deep-Sea Res., 29:739-766.

Calvert, S., 1983. Geochemistry of Pleistocene sapropels from the eastern Mediterranean. Oceanol. Acta, 6:255-267

Chamley, H., 1975. Sedimentation argileuse en mer Tyrrhenienne au Plio-Pleistocene d'apres l'etude du forage JOIDES 132. Bull. Groupe Fr. Arg., 27:97-137.

Channell, J.E.T., Rio, D., and Thunell, R. C., 1988. Miocene/Pliocene boundary magnetostratigraphy at Capo Spartivento, Calabria, Italy. Geology, 16:1096-1099.

Ciaranfi, N. and Cita, M. B., 1973. Paleontological evidence of changes in the Pliocene climates. In Ryan, W.B.F., Hsü, K. J., et al., Init. Repts. DSDP, 13: Washington, D.C. (U.S. Govt. Printing Office), 1387-1399.

Cifelli, R., 1974. Planktonic Foraminifera from the Mediterranean and adjacent Atlantic waters (Cruise 49 of the Atlantis II, 1969). J. Foraminiferal Res., 4: 171-183.

Cita, M. B., 1975. Studi sul Pliocene e gli strati di passagio del Miocene al Pliocene, VIII. Planktonic foraminiferal biozonation of the Mediterranean Pliocene deep sea record: a revision. Riv. Ital. Paleont. Stratigr., 81:527-544.

Cita, M. B. and Ryan, W.B.F., 1973. Time scale and general synthesis. In Ryan, W.B.F., Hsu, K., et al., Init. Repts. DSDP, 13: Washington, D.C. (U.S. Govt. Printing Office), 1405-1415. 
Colalongo, M. L., Pasini, G., Pelosio, G., Raffi, S., Rio, D., Ruggieri, G., Sartoni, S., Selli, R. and Sprovieri, R., 1982. The Neogene/ Quaternary boundary definition: a review and a proposal. Geogr. Fis. Din. Quat., 5:59-68.

Duplessy, J. C. 1972. La geochimie des isotopes stables du carbone dans la mer [Ph.D. dissert.]. University of Paris, Paris.

Ehrmann, L. and Keigwin, L., 1987. Middle Pliocene change in planktonic foraminiferal fauna at Site 606. In Ruddiman, W., Kidd, R., et al., Init. Repts. DSDP, 94: Washington, D.C. (U.S. Govt. Printing Office), 921-924.

Emiliani, C., 1955. Pleistocene temperature variations in the Mediterranean. Quaternaria, 3:87-98.

1966. Paleotemperature analysis of Caribbean cores P-6304-8 and P-6304-9 and a generalized temperature curve for the past 425,000 years. Jour. Geol., 74:109-124.

1974. Isotopic paleotemperatures and shell morphology of Globigerinoides rubra in Mediterranean deep-sea core 189. Micropaleontology, 20:106-109.

Emiliani, C., Mayeda, T. and Selli, R., 1961. Paleotemperature analysis of the Plio-Pleistocene section at Le Castella, Calabria, southern Italy. Geol. Soc. Am. Bull., 72:679-688.

Ganssen, G. M. and Troelstra, S. R., 1987. Paleoenvironmental change from stable isotopes in planktonic foraminifera from eastern Mediterranean sapropels. Mar. Geol., 75:210-218.

Hilgen, F. J., 1987. Sedimentary rhythms and high-resolution chronostratigraphic correlations in the Mediterranean Pliocene. Newsletter Stratigraphy, 17:109-127.

Hodell, D. A. and Kennett, J. P., 1986. Late Miocene-early Pliocene stratigraphy and paleoceanography of the South Atlantic and Southwest Pacific Oceans: A synthesis. Paleoceanography, 1:285-311.

Hodell, D. A., Kennett, J. P. and Leonard, K. A., 1983. Climaticallyinduced changes in vertical water mass structure of the Vema Channel during the Pliocene: evidence from DSDP Holes 516A, 517 and 518. In Barker, P. F., Carlson, R. L., Johnson, D. A., et al., Init. Repts. DSDP, 72: Washington, D.C. (U.S. Govt. Printing Office), 907-919.

Hsü, K. J., Montadert, L., Bernoulli, D., Cita, M. B., Erickson, A., Garrison, R. E., Kidd, R. B., Melieres, F., Müller, C. and Wright, R., 1977. History of the Mediterranean salinity crisis. Nature, 267: 399-403.

Jones, G. A. and Kaiteris, P., 1983. A vacuum-gasometric technique for rapid and precise analysis of calcium carbonate in sediments. J. Sed. Petrol., 53:655-660.

Keigwin, L. D., Jr., 1979. Late Cenozoic stable isotope stratigraphy and paleoceanography of DSDP sites from the east equatorial and central north Pacific Ocean. Earth Plan. Sci. Lett., 45: 361-382.

1982. Stable isotope stratigraphy and paleoceanography of Sites 502 and 503. In Prell, W. L., Gardner, J. V. et al., Init. Repts. DSDP, 68: Washington, D.C. (U.S. Govt. Printing Office), 445-453. 1987. Pliocene stable-isotope record of Deep Sea Drilling Project Site 606: sequential events of ${ }^{18} \mathrm{O}$ enrichment beginning at 3.1 Ma. In Ruddiman, W., Kidd, R., et al., Init. Repts. DSDP, 94: Washington, D.C. (U.S. Govt. Printing Office), 911-917.

Keigwin, L. D. and Thunell, R. C., 1979. Middle Pliocene climatic change in the western Mediterranean from faunal and oxygen isotopic trends. Nature, 282:292-296.

Keigwin, L. D., Aubry, M. P. and Kent, D. V., 1987. North Atlantic late Miocene stable-isotope stratigraphy, biostratigraphy and magnetostratigraphy. In Ruddiman, W., Kidd, R., et al., Init. Repts. DSDP, 94: Washington, D.C. (U.S. Govt. Printing Office), 935-963.

Kroopnick, P. M., 1985. The distribution of ${ }^{13} \mathrm{C}$ of $\Sigma \mathrm{CO}_{2}$ in the world oceans. Deep-sea Res., 32:57-84.

Lacombe, H., Gascard, J. C., Gonella, J. and Bethoux, J., 1981. Response of the Mediterranean to the water and energy fluxes across its surface, on seasonal and interannual scales. Oceanol. Acta, 4:247255.

Leonard, K. A., Williams, D. F. and Thunell, R. C., 1983. Pliocene paleoclimatic and paleoceanographic history of the South Atlantic Ocean: stable isotopic records from Leg 72 Deep Sea Drilling Project Holes 516A and 517. In Barker. P. F., Carlson, R. L., Johnson, D. A., et al., Init. Repts. DSDP, 72: Washington, D.C. (U.S. Govt. Printing Office), 895-906.

Martini, E., 1971. Standard Tertiary and Quaternary calcareous nannoplankton zonation. In Farinacci, A. (Ed.), Proc. II Planktonic Conf., Roma, 1970: Roma (Tecnoscienza), 739-785.
Okada, H. and Bukry, D., 1980. Supplementary modification and introduction of code numbers to the low latitude coccolith biostratigraphic zonation. Mar. Micropaleontol., 5: 321-325.

Pasini, G., Colalongo, M. and Sartoni, S. (in press). Sedimentology, biostratigraphy, magnetostratigraphy, biochronology and radiometric dating of the Vrica section in Calabria (Italy). In Van Couvering, J. (Ed.), The Pliocene/Pleistocene Boundary: Definition and Worldwide Correlation: Cambridge (Cambridge Univ. Press).

Pelosio, G., Raffi, I. and Rio, D., 1980. The Plio-Pleistocene Boundary Controversy: status in 1979 in light of the International Stratigraphic Guide. Universita degli Studi di Parma Grafiche Step Editrice, 131138.

Pisias, N. G. and Moore, T. C., 1981. The evolution of Pleistocene climate: a time series approach. Earth Plan. Sci. Lett., 52:450-458.

Prell, W. L., 1982. Oxygen and carbon isotope stratigraphy for the Quaternary of Hole 502B: evidence for two modes of isotopic variability. In Prell, W. L., Gardner, J. V. et al., Init. Repts. DSDP, 68: Washington, D.C. (U.S. Govt. Printing Office), 455-464.

1984. Covariance patterns of foraminiferal ${ }^{18} \mathrm{O}$ : An evaluation of Pliocene ice volume changes near 3.2 million years ago. Science, 226:692-294.

Raffi, I., and Rio, D., 1979. Calcareous nannofossil biostratigraphy of DSDP Site 132 Leg 13 (Tyrrhenian Sea-Western Mediterranean). Riv. Ital. Paleontol. Stratigr., 85:127-172.

Raymo, M., Ruddiman, W. and Clement, B., 1987. Pliocene-Pleistocene paleoceanography of the North Atlantic at Deep Sea Drilling Project Site 609. In Ruddiman, W., Kidd, R., et al., Init. Repts. DSDP, 94: Washington, D.C. (U.S. Govt. Printing Office), 895901.

Rio, D., Sprovieri, R. and Raffi, I., 1984. Calcareous plankton biostratigraphy and biochronology of the Pliocene-Lower Pleistocene succession of the Capo Rossello area, Sicily. Mar. Micropaleontol., 9: 135-180.

Rio, D., Backman, J. and Raffi, I., in press. Calcareous nannofossil biochronology and the Pliocene/Pleistocene Boundary. In Van Couvering, J. (Ed.), The Pliocene/Pleistocene Boundary: Definition and Worldwide Correlation: Cambridge (Cambridge University Press).

Rossignol-Strick, M., Nesteroff, W., Olive, P. and Vergnaud-Grazzini, C., 1982. After the deluge: Mediterranean stagnation and sapropel formation. Nature, 295:105-110.

Ruddiman, W. F. and Raymo, M., 1988. Northern Hemisphere climate regimes during the last 3 MYR: possible tectonic connections. Trans. Roy. Phil. Soc. London, 318:411-430.

Ruddiman, W. F., Raymo, M. and McIntyre, A., 1986. Matuyama 41,000-year cycles: North Atlantic Ocean and northern hemisphere ice sheets. Earth Plan. Sci. Lett., 80:117-129.

Ruddiman, W. F., McIntyre, A. and Raymo, M., 1987. Paleoenvironmental results from North Atlantic Sites 607 and 609. In Ruddiman, W., Kidd, R. et al., Init. Repts. DSDP, 94: Washington, D.C. (U.S. Govt. Printing Office), 855-878.

Selli, R. and others, 1977. The Vrica Section (Calabria, Italy). A Potential Neogene/Quaternary Boundary Stratotype. G. Geol., 42:181204.

Shackleton, N. J. and Opdyke, N. D., 1973. Oxygen-isotope and paleomagnetic stratigraphy of equatorial Pacific core V28-238: oxygen isotope temperatures and ice volume on a $10^{5}$ and $10^{6}$ year scale. Quat. Res., 3:39-55.

Shackleton, N. J. and Opdyke, N. D., 1976. Oxygen isotope and paleomagnetic stratigraphy of Pacific core V28-239 late Pliocene to late Pleistocene. In Cline, R. M. and Hays, J. D. (Eds.), Investigations of Late Quaternary Paleoceanography and Paleoclimatology, Geol. Soc. Am. Mem., 145:449-464.

1977. Oxygen isotope and paleomagnetic evidence for early Northern Hemisphere glaciation. Nature, 270:216-219.

Shackleton, N. J. and Vincent, E., 1978. Oxygen and carbon isotope studies in recent foraminifera from the S.W. Indian Ocean. Mar. Micropaleontol., 3:1-13.

Shackleton, N. J. and Cita, M. B., 1979. Oxygen and carbon isotope stratigraphy of benthic foraminifers at Site 397: detailed history of climatic change during the late Neogene. In von Rad, U., Ryan, W.B.F. et al., Init. Repts. DSDP, 47: Washington, D.C. (U.S. Govt. Printing Office), 433-459.

Shackleton, N. J., Backman, J., Zimmerman, H., Kent, D. V., Hall, M. A., Roberts, D. G., Schnitker, D., Baldauf, J. G., Desprairies, A., Kaltenback, A. J., Krumsiek, K.A.O., Morton, A. C., Murray, 
J. W., and Westberg-Smith, J., 1984. Oxygen isotope calibration of the onset of ice-rafting and the history of glaciation in the North Atlantic region. Nature, 307:620-623.

Spaak, P., 1983. Accuracy in correlation and ecological aspects of the planktonic foraminiferal zonation of the Mediterranean Pliocene. Utrecht Micropaleontol. Bull., 28:1-160.

Sprovieri, R., 1976. Remarks on the Early Pliocene Trubi for Sicily. Mem. Soc. Geol. It., 16:159-163.

Sprovieri, R., 1978. I foraminifieri bentonici della sezione Plio-Pleistocenica di Capo Rossello (Agrigento, Sicily). Boll. Soc. Palentol. Ital., 17:68-97.

Tauxe, L., Opdyke, N. D., Pasini, G. and Elmi, C., 1983. Age of the Plio-Pleistocene boundary in the Vrica section, southern Italy. $\mathrm{Na}$ ture, 304:125-129.

Thiede, J., 1978. A glacial Mediterranean. Nature, 276:680-683.

Thierstein, H., Geitzenauer, K., Molfino, B. and Shackleton, N., 1977. Global synchroneity of late Quaternary coccolith datum levels: validation by oxygen isotopes. Geology, 5:400-404.

Thunell, R. C., 1979. Climatic evolution of the Mediterranean Sea during the last 5.0 million years. Sed. Geol., 23:67-79.

Thunell, R. C. and Belyea, P., 1982. Neogene planktonic foraminiferal biogeography of the Atlantic Ocean. Micropaleontology, 28:281298.

Thunell, R. C. and Williams, D. F., 1983a. The stepwise development of Pliocene-Pleistocene paleoclimatic and paleoceanographic conditions in the Mediterranean: oxygen isotope studies of DSDP Sites 125 and 132. Utrecht Micropaleontol. Bull., 30:11-127.

, 1983b. Paleotemperature and paleosalinity history of the eastern Mediterranean during the late Quaternary. Paleogeog., Paleoclim., Paleoecol., 44:23-39.

Thunell, R. C., Williams, D. F. and Kennett, J. P., 1977. Late Quaternary paleoclimatology, stratigraphy and sapropel history in eastern Mediterranean deep sea sediments. Mar. Micropaleontol., 2:371388.

Thunell, R. C., Williams, D. F. and Cita, M. B., 1983. Glacial anoxia in the eastern Mediterranean. J. Foram. Res., 13:283-290.

Thunell, R. C., Williams, D. F. and Belyea, P., 1984. Anoxic events in the Mediterranean Sea in relation to the evolution of late Neogene climates. Mar. Geol., 59:105-134.

Thunell, R., Williams, D., Raffi, I., Rio, D. and Sprovieri, R., 1985. Pliocene-Pleistocene history of the Mediterranean: Results from deepsea and land-based marine records. Terra Cognita, 5:89.

Thunell, R., Williams, D. and Howell, M., 1987. Atlantic-Mediterranean water exchange during the late Neogene. Paleoceanography, 2: 661-678.

Thunell, R., Rio, D., Channell, J. and Sprovieri, R., 1987. The Miocene/Pliocene boundary and earliest Pliocene paleoenvironment of the Capo Spartivento section, Calabria, southern Italy. Fourth Inter. Conf. Pacific Neogene Strat., Berkeley, 118.

Van Couvering, J. A., Berggren, W. A., Drake, R., Aguirre, E. and Curtis, G. H., 1976. The terminal Miocene event. Mar. Micropaleontol., 1:263-286.
Van Der Zwaan, G. J., 1983. Quantitative analyses and the reconstruction of benthic foraminiferal communities. Utrecht Micropaleontol. Bull., 30:49-69.

Van der Zwaan, G. and Gudjonsson, L., 1986. Middle Miocene-Pliocene stable isotope stratigraphy and paleoceanography of the Mediterranean. Mar. Micropaleontol., 10:71-90.

van Donk, J., 1976. ${ }^{18} \mathrm{O}$ record of the Atlantic Ocean for the entire Pleistocene Epoch. In Cline, R. M., and Hays, J. D. (Eds.), Investigation of late Quaternary paleoceanography and paleoclimatology. Mem. Geol. Soc. Am., 145:147-163.

Vergnaud-Grazzini, C., $1975 .{ }^{18} \mathrm{O}$ changes in foraminiferal carbonates during the last $10^{5}$ years in the Mediterranean Sea. Science, 190:272274.

Vergnaud-Grazzini, C., 1983. Reconstruction of Mediterranean late Cenozoic hydrography by means of carbon isotope analyses. Utrecht Micropaleontol. Bull., 30:35-47.

Vergnaud-Grazzini, C., 1985. Mediterranean late Cenozoic stable isotope record: stratigraphic and paleoclimatic implications. In Stanley, D. J., and Wezel, F. C., (Eds.), Geological Evolution of the Mediterranean Basin: New York (Springer-Verlag), 413-451.

Vergnaud-Grazzini, C., Ryan, W. and Cita, M. B., 1977. Stable isotopic fractionation, climate change and episodic stagnation in the eastern Mediterranean during the late Quaternary. Mar. Micropaleontol., 2: 353-370.

Vergnaud-Grazzini, C., Devaux, M. and Znaidi, J., 1986. Stable isotope anomalies in Mediterranean Pleistocene records. Mar. Micropaleontol., 10:35-69.

Williams, D. F., Sommer, M. A. and Bender, M. L., 1977. Carbon isotopic compositions of recent planktonic foraminifera of the Indian Ocean. Earth Plan. Sci. Lett., 36:391-403.

Williams, D. F., Thunell R. C., and Kennett J. P., 1978. Periodic fresh water flooding and stagnation of the eastern Mediterranean during the late Quaternary. Science, 201:252-254.

Williams, D. F., Thunell, R. C., Tappa, E. J., Rio, D. and Raffi, I., 1988. Chronology of the Pleistocene oxygen isotope record: $0-1.88$ million years before present. Paleogeog., Paleoclim., Paleoecol., 64: 221-240.

Zachariasse, W. J. and Spaak, P., 1983. Middle Miocene to Pliocene paleoenvironmental reconstruction of the Mediterranean and adjacent Atlantic Ocean: planktonic foraminiferal record of southern Italy. Utrecht Micropaleont. Bull., 30:91-110.

Zijderveld, J., Zachariasse, J., Verhallen, P. and Hilgen, F., 1986. The age of the Miocene-Pliocene boundary. Newsletter Stratigraghy, 16: 169-181.

Date of initial receipt: 9 November 1987

Date of acceptance: 17 January 1989

MS 107B-155 